Stefan Lauterbach | Roman Witt | Birgit Plessen | Peter Dulski Sushma Prasad | Jens Mingram | Gerd Gleixner Sabine Hettler-Riedel | Martina Stebich | Bernhard Schnetger Antje Schwalb | Anja Schwarz

\title{
Climatic imprint of the mid-latitude Westerlies in the Central Tian Shan of Kyrgyzstan and teleconnections to North Atlantic climate variability during the last 6000 years
}

Suggested citation referring to the original publication:

The Holocene 24(8) (2014), pp. 970-984

DOI http://dx.doi.org/10.1177/0959683614534741

ISSN (online) 1477-0911

ISSN (print) 0959-6836

Postprint archived at the Institutional Repository of the Potsdam University in:

Postprints der Universität Potsdam

Mathematisch-Naturwissenschaftliche Reihe ; 408

ISSN 1866-8372

http://nbn-resolving.de/urn:nbn:de:kobv:517-opus4-404085 



\title{
Climatic imprint of the mid-latitude Westerlies in the Central Tian Shan of Kyrgyzstan and teleconnections to North Atlantic climate variability during the last 6000 years
}

The Holocene

2014, Vol. 24(8) 970-984

(C) The Author(s) 2014

Reprints and permissions: sagepub.co.uk/journalsPermissions.nav DOI: $10.1|77 / 09596836| 453474$ | hol.sagepub.com

\author{
Stefan Lauterbach,' Roman Witt, ${ }^{2}$ Birgit Plessen,' Peter \\ Dulski,' Sushma Prasad, ',3 Jens Mingram,' Gerd Gleixner, ${ }^{2}$ Sabine \\ Hettler-Riedel, ${ }^{4}$ Martina Stebich, ${ }^{4}$ Bernhard Schnetger, ${ }^{5}$ Antje \\ Schwalb ${ }^{6}$ and Anja Schwarz ${ }^{6}$
}

\begin{abstract}
In general, a moderate drying trend is observed in mid-latitude arid Central Asia since the Mid-Holocene, attributed to the progressively weakening influence of the mid-latitude Westerlies on regional climate. However, as the spatio-temporal pattern of this development and the underlying climatic mechanisms are yet not fully understood, new high-resolution paleoclimate records from this region are needed. Within this study, a sediment core from Lake Son Kol (Central Kyrgyzstan) was investigated using sedimentological, (bio)geochemical, isotopic, and palynological analyses, aiming at reconstructing regional climate development during the last 6000 years. Biogeochemical data, mainly reflecting summer moisture conditions, indicate predominantly wet conditions until 4950 cal. yr BP, succeeded by a pronounced dry interval between 4950 and 3900 cal. yr BP. In the following, a return to wet conditions and a subsequent moderate drying trend until present times are observed. This is consistent with other regional paleoclimate records and likely reflects the gradual Late Holocene diminishment of the amount of summer moisture provided by the mid-latitude Westerlies. However, climate impact of the Westerlies was apparently not only restricted to the summer season but also significant during winter as indicated by recurrent episodes of enhanced allochthonous input through snowmelt, occurring before $6000 \mathrm{cal}$. yr BP and at 5I00-4350, 3450-2850, and I900-1500 cal. yr BP. The distinct I500year periodicity of these episodes of increased winter precipitation in Central Kyrgyzstan resembles similar cyclicities observed in paleoclimate records around the North Atlantic, likely indicating a hemispheric-scale climatic teleconnection and an impact of North Atlantic Oscillation (NAO) variability in Central Asia.
\end{abstract}

\section{Keywords}

Central Asia, climate, Holocene, lake sediments, mid-latitude Westerlies, NAO

Received 27 November 2013; revised manuscript accepted 10 April 2014

\section{Introduction}

Reliably assessing the ecosystem impact of future human-induced climate change requires a profound understanding of past natural climate variability. This is especially crucial in climatologically extreme areas, for example, at high altitudes, where the consequences of future global warming are expected to be most severe (Solomon et al., 2007). In this context, the Tian Shan in Central Asia is of particular interest, as it represents the headwaters for several large rivers (e.g. Syr Darya, Tarim), and future climateinduced water shortage there may affect human subsistence across large parts of western Central Asia. Furthermore, being located at the intercept between the influences of the mid-latitude Westerlies, the Siberian Anticyclone, and partly also the Asian monsoon system (Cheng et al., 2012), the region holds information about hemispheric-scale climatic teleconnections, necessary to understand the global climate system. However, although the Tian Shan is thus of key importance for climate studies and various types of natural archives, for example, speleothems (Cheng et al., 2012), tree-rings (Esper et al., 2003), or loess sequences (Machalett
'GFZ German Research Centre for Geosciences, Section 5.2 Climate Dynamics and Landscape Evolution, Potstdam,

Germany

2Max Planck Institute for Biogeochemistry, Research Group Molecular Biogeochemistry, Jena, Germany

${ }^{3}$ University of Potsdam, Institute of Earth and Environmental Science, Potsdam, Germany

${ }^{4}$ Senckenberg Research Institute, Research Station of Quaternary Paleontology, Weimar, Germany

${ }^{5} \mathrm{Carl}$ von Ossietzky University, Institute for Chemistry and Biology of the Marine Environment, Oldenburg, Germany

${ }^{6}$ Technical University Braunschweig, Institute of Geosystems and Bioindication, Braunschweig, Germany

Corresponding author:

Stefan Lauterbach, Section 5.2 - Climate Dynamics and Landscape Evolution, GFZ German Research Centre for Geosciences, Telegrafenberg C109, I4473 Potsdam, Germany.

Email: stefan.lauterbach@gfz-potsdam.de 

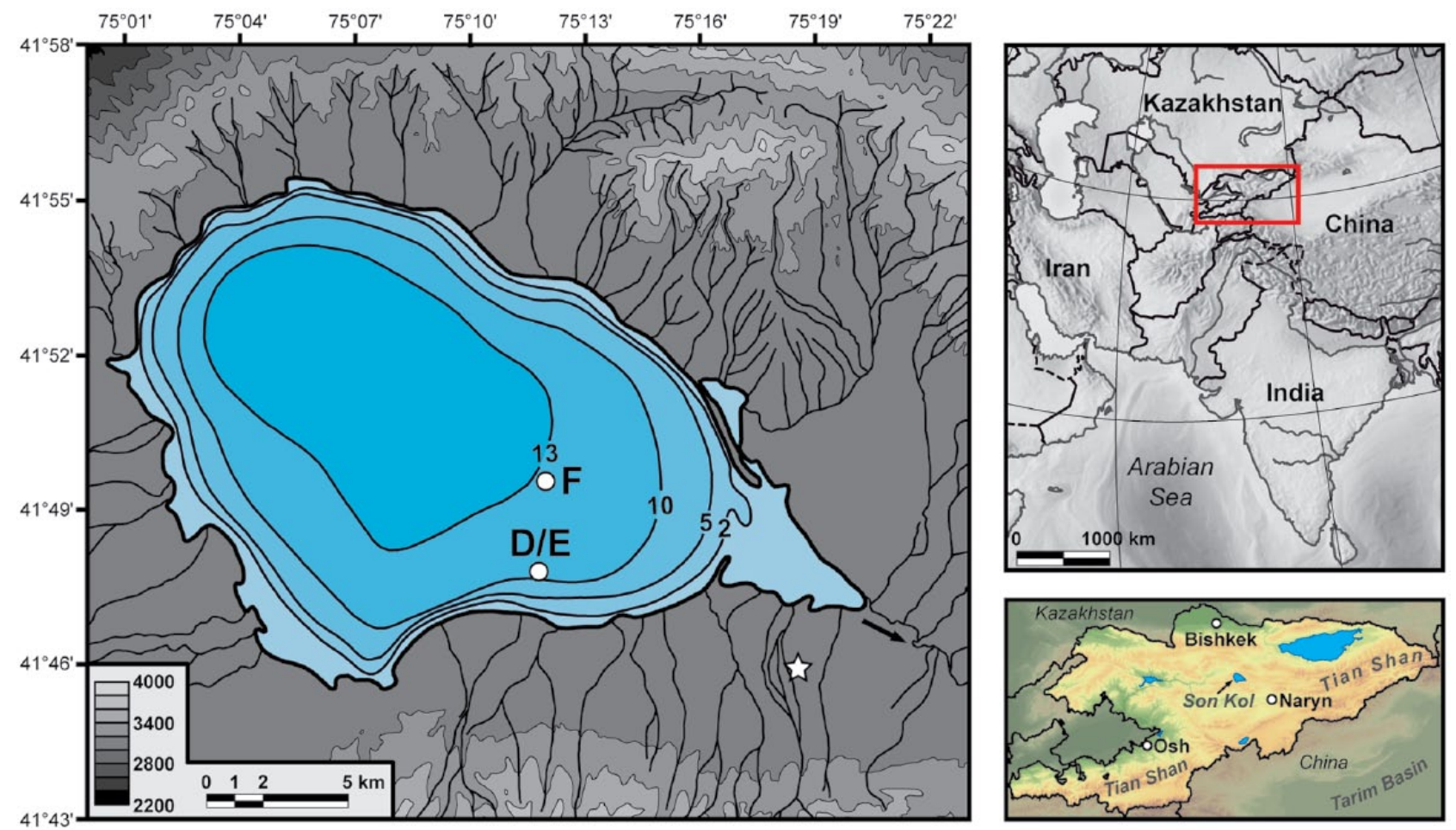

Figure I. Location of Son Kol with bathymetric map of the lake (isobaths with corresponding water depths in meters below lake level) and relief of the surrounding area (elevations in meters a.s.I.). The coring sites $\mathrm{D} / \mathrm{E}$ and $\mathrm{F}$ are indicated by white points (at site $\mathrm{F}$, a mooring with water temperature loggers was installed) and the position of the air temperature logger is marked by a white star.The relief map of Kyrgyzstan is based on the CGIAR-CSI SRTM 90 m (3 arcsec) digital elevation data (Version 4) of the NASA Shuttle Radar Topography Mission (Jarvis et al., 2008).

et al., 2008) have been analyzed in this respect so far, knowledge about Holocene climate development and particularly hydrological changes in this region is still limited. For example, a moderate drying trend due to the gradual decline of moisture supplied by the Westerlies has been inferred for mid-latitude arid Central Asia since the Mid-Holocene from lake sediment records (Chen et al., 2008). Nevertheless, this might be spatially more complex as there were apparently significant differences in past climate development between the western and eastern parts of Central Asia (Kleinen et al., 2011; Rudaya et al., 2009) owed to the interplay of different climatic systems in the region. In order to provide more detailed insights into Holocene climate development in the western part of arid Central Asia, several lake sediment records (which are particularly valuable paleoclimate archives because of the robust age control, the high temporal resolution and the variety of climate-related proxy parameters to be investigated) from NW China (An et al., 2012; Li et al., 2011; Mischke and Wünnemann, 2006; Wünnemann et al., 2006), Tajikistan (Mischke et al., 2010), Kazakhstan (Boomer et al., 2000; Huang et al., 2011; Sorrel et al., 2006), and Kyrgyzstan (Beer et al., 2007; Mathis et al., 2014; Ricketts et al., 2001) have been studied so far, but further investigations are necessary to fully disentangle the complex climatic history and interfering interplays between the different climatic systems in this region.

As a part of the project CADY (Central Asian Climate Dynam$i c s$, aiming at reconstructing Holocene climate development in Central Asia, a sediment core from Son Kol, a lake in the Central Kyrgyz Tian Shan, was investigated within this study. The potential of this lake for regional paleoclimate reconstructions has recently been demonstrated by Huang et al. (2012) and Mathis et al. (2014). However, as the sediment core investigated in these studies missed the last 2000 years because of coring problems, we opted for a new, more complete core and applied additional highresolution analyses. The new sediment core, covering the last $c$.
6000 years, was investigated using sediment microfacies analysis, high-resolution $\mu \mathrm{XRF}$ element scanning and stable isotope, (bio) geochemical and pollen analyses in order to provide new, more detailed information on regional climate development since the Mid-Holocene and to shed light on climatic teleconnections, particularly the regional influence of the mid-latitude Westerlies.

\section{Study site}

Lake Son Kol (also transcribed Son Kul, Sonkul, Song-Kul) is located at $3016 \mathrm{~m}$ a.s.1. (above sea level) in the Central Tian Shan of Kyrgyzstan, about $80 \mathrm{~km}$ northwest of the town Naryn (Figure 1). The lake is at maximum $\sim 29 \mathrm{~km}$ long and $\sim 18 \mathrm{~km}$ wide (surface area $\sim 273 \mathrm{~km}^{2}$, maximum depth $\sim 13 \mathrm{~m}$ ) and occupies the central part of an about $60 \times 30 \mathrm{~km}$ large high-alpine valley (catchment area $\sim 1130 \mathrm{~km}^{2}$ ), which is surrounded by the mountains of the Son Kol Too and Baidula Ranges in the north and the Boor Albas Range in the south, reaching elevations of 3800-4000 $\mathrm{m}$ a.s.l. (Shnitnikov, 1980). These mountain ranges are composed of Cambro-Ordovician, Carboniferous and Permian granitoids, gabbros, metamorphites, and sedimentary rocks (De Grave et al., 2011), while the extensive pasture-covered plains around the lake mainly consist of Quaternary erosion material from the mountains. Besides receiving water from groundwater inflow and precipitation on its surface, the lake is predominantly fed by rainfall and snowmelt runoff, provided by several mostly perennial tributaries. The lake is drained by a single outlet at its eastern end, which discharges into the Naryn River and finally into the Syr Darya.

The local high-alpine climate is characterized by short temperate summers and severely cold winters with snow cover between November and April. The long-term average annual air temperature is about $-3.5^{\circ} \mathrm{C}$, with January and July means 

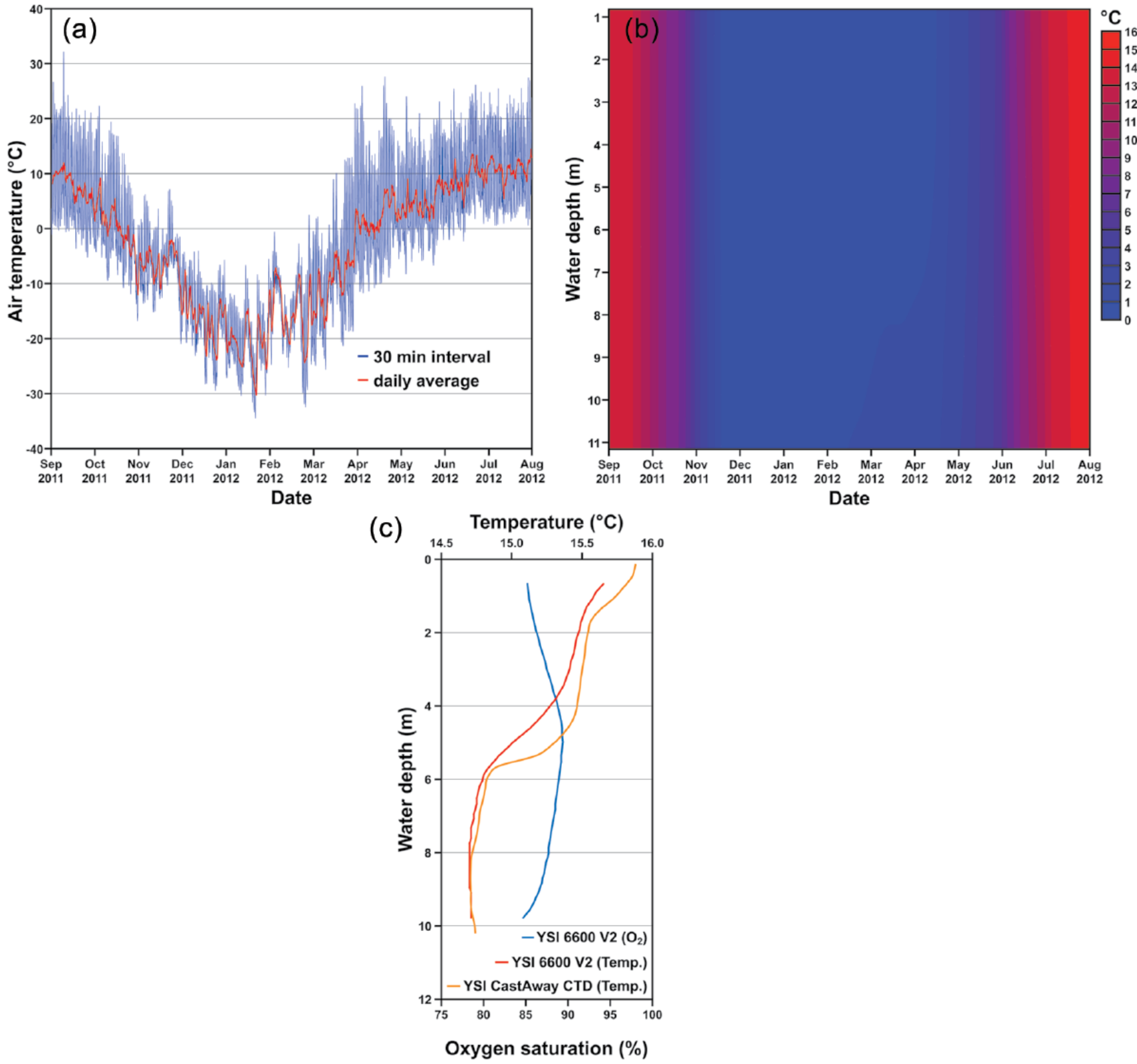

Figure 2. Results of air (a) and water temperature (b) measurements in 30-min intervals, carried out with HOBO Water Temperature Pro v2 data loggers between I September 20II and 3I July 20I2. Air temperature measurements were carried out $2 \mathrm{~m}$ above ground surface at a sun-shielded, north-facing site (Figure I). Water temperature loggers were installed on a mooring at coring site F (Figure I) in I-m increments between 2 and $10 \mathrm{~m}$ water depth. The acquired water temperature data are displayed as a contour plot gridded with Grapher 7. Point measurements of water oxygen saturation and temperature (c) were carried out at 31 July 2012 at coring site $D$ across the water column by using YSI 6600V2 and YSI CastAway CTD multi-parameter water probes.

of about $-20^{\circ} \mathrm{C}$ and $10^{\circ} \mathrm{C}$, respectively (Academy of Science of the Kyrgyz SSR, 1987; Shnitnikov, 1980), which is mainly confirmed by own measurements (Figure 2a). Lake water temperature ranges between $\sim 16^{\circ} \mathrm{C}$ in summer and $0-2^{\circ} \mathrm{C}$ in winter (ice cover usually between October and late April) with almost no vertical variations $\left(<2^{\circ} \mathrm{C}\right)$ throughout the water column (Figure $2 \mathrm{~b}$ and $\mathrm{c}$ ). The precipitation regime in the Kyrgyz Tian Shan is presently mainly controlled by the interaction between the Siberian Anticyclone and the mid-latitude Westerlies (Aizen et al., 1997), the latter bringing moisture from the Aral-Caspian Basin, the Mediterranean, the Black Sea, and the North Atlantic (Aizen et al., 2006). In contrast, the Asian summer monsoon does not directly influence the region at present and most likely had only negligible impact since the Mid-Holocene (Cheng et al., 2012). Owed to orographic effects, the spatial distribution of precipitation in the region is strongly heterogeneous
(Academy of Science of the Kyrgyz SSR, 1987; Böhner, 2006) as clearly displayed by recent data: while at the Dolon Pass $\left(41^{\circ} 50^{\prime} 24^{\prime \prime} \mathrm{N}, 75^{\circ} 44^{\prime} 30^{\prime \prime} \mathrm{E}, 3030 \mathrm{~m}\right.$ a.s.1.), about $50 \mathrm{~km}$ east of Son Kol, the average annual precipitation amounts to $\sim 400 \mathrm{~mm}$ (Williams and Konovalov, 2008), it is clearly higher at the lake itself (500-600 mm; Academy of Science of the Kyrgyz SSR, 1987). Most of the precipitation in the area occurs as convective rainfall during summer, driven by moist westerly air masses (Aizen et al., 2001), whereas only about $20 \%$ fall between November and March (Academy of Science of the Kyrgyz SSR, 1987) because of the blocking of the Westerlies by the Siberian Anticyclone in winter.

Owing to the high altitude and the associated extreme climate conditions, the local vegetation is characterized by montane steppe and meadow communities, dominated by Poaceae (e.g. Festuca), Artemisia, and alpine elements (e.g. Gentiana). 

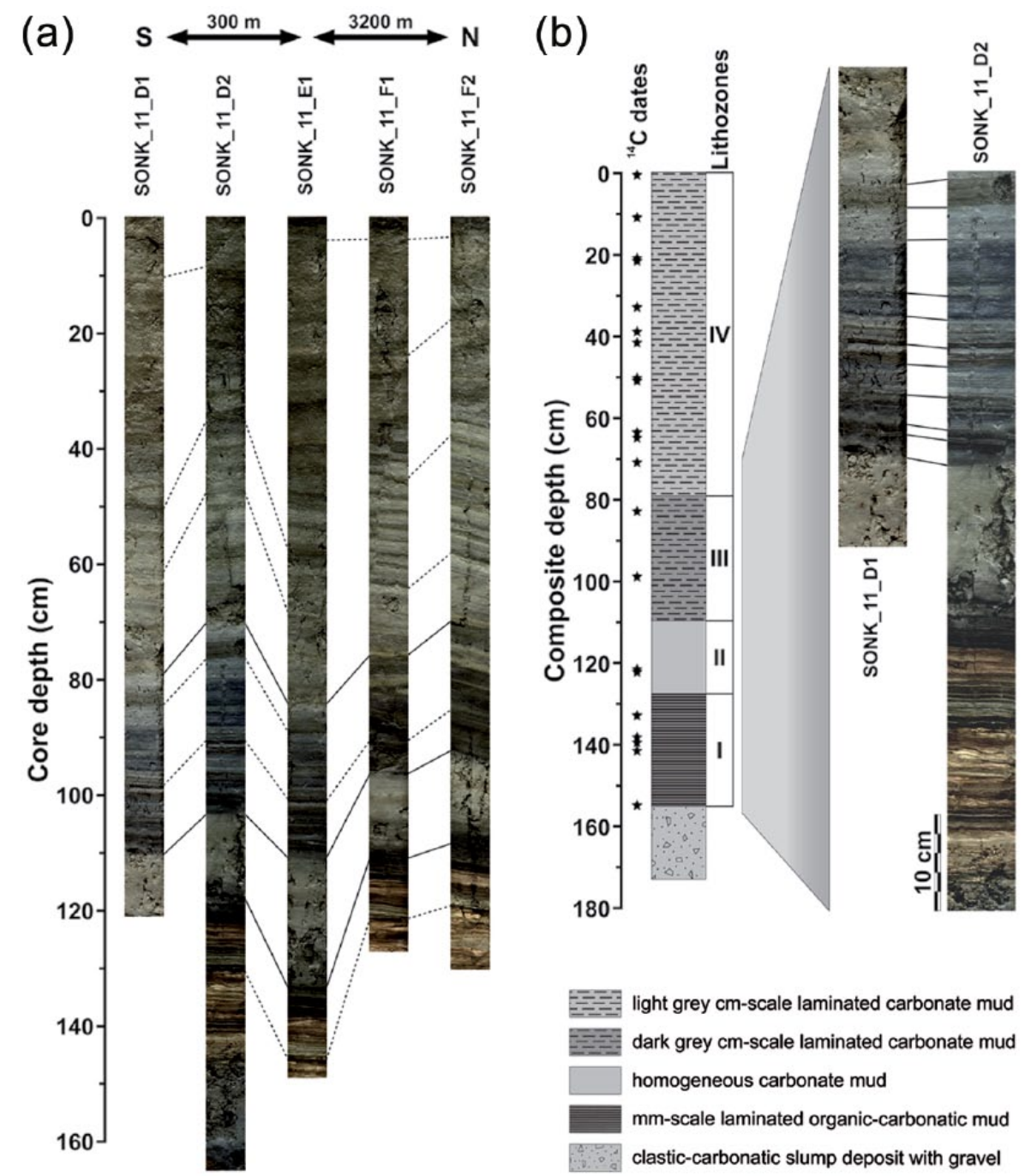

Figure 3. (a) General correlation between the five sediment cores obtained from Son Kol. Solid lines indicate boundaries of major lithostratigraphical units, dashed lines further correlation layers. For details concerning the location of the cores, see Figure I. (b) Schematic lithological profile and corresponding lithostratigraphical units of the composite profile SONK_II_DI/2. Detail photographs of the two sediment cores SONK_II_DI and SONK_II_D2 illustrate the close agreement between both cores and the correlation through distinct lithological marker layers.

Resulting from high grazing pressure, dwarfed individuals of most taxa and grazing-resistant species (e.g. Leontopodium) dominate. Local tree-stands (mainly Picea schrenkiana) occur only beyond the surrounding mountain ranges up to altitudes of $\sim 3000$ $\mathrm{m}$ a.s.l. Most of the shore areas are covered by sedge marsh (mainly Carex and Kobresia), and large parts of the lake bottom down to water depths of at least 7-8 $\mathrm{m}$ are covered by submerged macrophytes (e.g. Myriophyllum) and algae (e.g. Chara).

\section{Methods}

\section{Fieldwork and sampling}

Five gravity cores of about $120-165 \mathrm{~cm}$ length were obtained in August 2011 from three different sites in the eastern part of Son Kol (D: $41^{\circ} 47^{\prime} 38^{\prime \prime} \mathrm{N}, 75^{\circ} 11^{\prime} 49^{\prime \prime} \mathrm{E}, 10.5 \mathrm{~m}$ water depth; E: $41^{\circ} 47^{\prime} 48^{\prime \prime} \mathrm{N}$, $75^{\circ} 11^{\prime} 47^{\prime \prime} \mathrm{E}, 11.5 \mathrm{~m}$ water depth; F: $41^{\circ} 49^{\prime} 31^{\prime \prime} \mathrm{N}, 75^{\circ} 12^{\prime} 03^{\prime \prime} \mathrm{E}, 12.5$ $m$ water depth; Figure 1) by using a $90-\mathrm{mm}$ UWITEC gravity corer with additional hammer weight. Despite the large distances between the sites and likely associated spatial differences in sediment distribution within the lake basin, all cores reveal a generally similar sediment composition (Figure 3a, Supplementary Figure S1 and Table S1, available online). As the two cores from site D (SONK_11_D1 and SONK_11_D2), which is located $\sim 2 \mathrm{~km}$ off a large fluvial fan at the southern lake shore (Figure 1), contained the longest sediment sequence, a $\sim 175$-cm-long composite profile (SONK_11_D1/2) was constructed from these cores by correlating them via distinct lithological marker layers (Figure 3b). Following core opening, photographing, and lithostratigraphical description, one half of the composite profile was kept for non-destructive corescanning analyses, while the second was subsampled for sedimentological, isotopic, (bio)geochemical, and micropaleontological analyses as well as for radiocarbon dating.

To identify the imprint of different types of organic matter $(\mathrm{OM})$ in the lake sediments, several samples of terrestrial and aquatic plants, algae, and dung from different herbivores, representing the digested residue of terrestrial plant material (Supplementary Table S2, available online), were collected from the lake and its catchment during field campaigns in summer 2011 and 2012. In addition, several samples of catchment soils were taken from different depth intervals (Supplementary Table S2, available online). All samples were air-dried in the field, and soil samples were additionally sieved at $2 \mathrm{~mm}$ mesh size.

\section{Sediment microfacies and geochemical/isotopic analyses}

Sediment microfacies analysis was carried out on large-scale petrographic thin sections, prepared according to Brauer et al. 
(1999), by using a ZEISS Axiophot polarization microscope at 25-400× magnification. High-resolution major element scanning was performed on the foil-covered fresh surface of the split sediment cores by using a vacuum-operating Itrax micro $\mathrm{x}$-ray fluorescence ( $\mu \mathrm{XRF}$ ) core scanner (Croudace et al., 2006) equipped with a Cr x-ray tube (tube voltage $30 \mathrm{kV}$, tube current $30 \mathrm{~mA}, 200$ $\mu \mathrm{m}$ resolution, $10 \mathrm{~s}$ exposure time, single scan line). Measured element intensities for Ti and $\mathrm{K}$ are reported as counts per $10 \mathrm{~s}$, semi-quantitatively representing relative changes in element concentration. To further characterize the composition of the lake sediments, selected freeze-dried and homogenized samples were analyzed by $x$-ray diffractometry using a PANalytical Empyrean diffractometer with a $\mathrm{Cu} \mathrm{K \alpha}$ x-ray tube operating at $40 \mathrm{kV}$ and 40 $\mathrm{mA}$. Diffraction data were recorded from $5^{\circ}$ to $85^{\circ}(2 \theta)$ with a continuous step width of $0.013^{\circ}$ (60 s scan time per step) and analyzed with the Rietveld algorithm Autoquan/BGMN (Bergmann et al., 1998).

For geochemical/isotopic analyses, 0.5 -cm-thick sediment slices were taken continuously from the composite profile, followed by freeze-drying and homogenization. For analysis of the total organic carbon (TOC) content and the stable carbon isotope ratio of the organic fraction $\left(\delta^{13} \mathrm{C}_{\mathrm{org}}\right), 1-3 \mathrm{mg}$ sediment were placed in $\mathrm{Ag}$ capsules, treated with $20 \% \mathrm{HCl}$ at $75^{\circ} \mathrm{C}$, and subsequently processed in a Carlo Erba NC 2500 elemental analyzer coupled to a Finnigan DELTAplusXL isotope ratio mass spectrometer (IRMS). Total nitrogen (TN) content and stable nitrogen isotope ratio $\left(\delta^{15} \mathrm{~N}\right)$ measurements were carried out with the same analytical facility $(15-50 \mathrm{mg}$ sediment in Sn capsules, no acid treatment). Geochemical and isotopic analyses of plant, soil, and dung samples were carried out in a similar manner as for the lake sediments with $10-15 \mathrm{mg}$ sample material for TOC, TN, and $\delta^{15} \mathrm{~N}$ analyses and $\sim 0.5 \mathrm{mg}$ for $\delta^{13} \mathrm{C}_{\text {org }}$ analyses being used. For all analyzed samples, the TOC and TN contents were used to calculate the atomic $\mathrm{C} / \mathrm{N}$ ratio. Results of the TOC and $\mathrm{TN}$ analyses are expressed as percent of dry weight, while those of the $\delta^{13} \mathrm{C}_{\mathrm{org}}$ and $\delta^{15} \mathrm{~N}$ measurements are expressed in the conventional $\delta$-notation relative to the Vienna PeeDee Belemnite (VPDB) and atmospheric nitrogen (AIR) standards, respectively. Based on repeated measurements of international reference standards (IAEA CH-7, N-1, N-2, USGS24), the precision of the elemental and isotopic analyses is $<0.2 \%$ and $<0.2 \%$, respectively.

\section{Biogeochemical analyses}

To determine the $n$-alkane composition of the lake sediments, $0.3-1.3 \mathrm{~g}$ dried and homogenized sediment (average sample increment $1-2 \mathrm{~cm}$ ) were processed in a DIONEX ASE 200 accelerated solvent extractor, operating at $100^{\circ} \mathrm{C}$ and 137 bar for 15 min in two cycles and using a 9:1 (v/v) $\mathrm{CH}_{2} \mathrm{Cl}_{2} / \mathrm{CH}_{3} \mathrm{OH}$ solvent mixture. $\mathrm{HCl}$-activated copper was added to remove elemental sulfur. The total lipid extract was separated using solid phase extraction on silica gel $(0.040-0.063 \mathrm{~mm}$ mesh) according to Sachse et al. (2006), and the $n$-alkane fraction was eluted with 80 $\mathrm{mL} n$-hexane. Identification and quantification of the $n$-alkanes were accomplished using a ThermoQuest TRACE GC 2000 gas chromatograph (GC), equipped with a flame ionization detector (FID) and an Agilent Technologies DB-1MS column (30 m length, $0.25 \mathrm{~mm} \mathrm{ID}, 0.25 \mu \mathrm{m}$ film thickness), and comparing results with an external $n$-alkane standard mixture $\left(n-\mathrm{C}_{10}\right.$ to $n$ $\mathrm{C}_{34}$ ). The PTV injector was operated in splitless mode with an initial temperature of $45^{\circ} \mathrm{C}$ for $0.1 \mathrm{~min}$, then heated up with $14.5^{\circ} \mathrm{C} / \mathrm{s}$ to $300^{\circ} \mathrm{C}$ and held there for $3 \mathrm{~min}$. The $\mathrm{GC}$ oven was held at $90^{\circ} \mathrm{C}$ for $1 \mathrm{~min}$, raised with $10^{\circ} \mathrm{C} / \mathrm{min}$ to $300^{\circ} \mathrm{C}$, held there for $9 \mathrm{~min}$, and finally heated with $30^{\circ} \mathrm{C} / \mathrm{min}$ to $335^{\circ} \mathrm{C}$ and held there for $3 \mathrm{~min}$. The He carrier gas flow was held constant at $2 \mathrm{~mL} / \mathrm{min}$. The FID was operated at $300^{\circ} \mathrm{C}$ and with gas flows of 40,45 , and $450 \mathrm{~mL} / \mathrm{min}$ for synthetic air, $\mathrm{H}_{2}$ and $\mathrm{N}_{2}$, respectively.

Stable hydrogen isotope ratios of the $n$-alkane $n-\mathrm{C}_{29}\left(\delta \mathrm{D}_{n \text {-C29 }}\right)$ were analyzed using a coupled GC-IRMS system. Samples were injected into an Agilent Technologies HP5890 Series II GC system equipped with a SGE BP1 column $(60 \mathrm{~m}, 0.32 \mathrm{~mm}$ ID, 0.50 $\mu \mathrm{m}$ film thickness). The injector was operated at $280^{\circ} \mathrm{C}$ in splitless mode. The oven was maintained for $1 \mathrm{~min}$ at $60^{\circ} \mathrm{C}$, heated with $10^{\circ} \mathrm{C} / \mathrm{min}$ to $300^{\circ} \mathrm{C}$, and held there for $28.5 \mathrm{~min}$. The final ramp heated with $20^{\circ} \mathrm{C} / \mathrm{min}$ to $340^{\circ} \mathrm{C}$, where it was held for 3 min. The column flow was constant at $2 \mathrm{~mL} / \mathrm{min} ; 5 \%$ of the gas flow were transferred to a ThermoElectron GCQ ion trap mass spectrometer for identifying mass fragments and $95 \%$ went to a Finnigan DELTAplus XL IRMS. $\delta \mathrm{D}_{n \text {-C29 }}$ was determined in triplicate measurements and is reported in the conventional $\delta$-notation relative to the Vienna Standard Mean Ocean Water (VSMOW) standard. An offset calculation was accomplished using $\mathrm{H}_{2}$ reference gas of known isotopic composition and correcting measured $\delta \mathrm{D}$ values $(n=7)$ of a standard mixture $\left(n-\mathrm{C}_{10}\right.$ to $\left.n-\mathrm{C}_{34}\right)$. When necessary, a drift correction was applied, determined by measuring standards every third sample (Werner and Brand, 2001). The $\mathrm{H}_{3+}$ factor was determined daily and stayed constant within the analytical error at $10.78(\mathrm{SD}=1.61, n=19)$ during the measurement period.

\section{Pollen analyses}

For pollen analyses, $1 \mathrm{~cm}^{3}$ sediment samples were taken from the composite profile (average increment $5 \mathrm{~cm}$ ) and prepared with $\mathrm{HCl}, \mathrm{KOH}, \mathrm{HF}$, and hot acetolysis mixture, following standard methods (Berglund and Ralska-Jasiewiczowa, 1986). A defined quantity of Lycopodium spores was added to each sample to calculate the pollen concentration as pollen grains per $\mathrm{cm}^{3}$ dry sediment (Stockmarr, 1971). Sample residues were stained with safranine and mounted in glycerine, and on average 1000 terrestrial pollen grains per sample were counted and identified using the reference collection of the Senckenberg Research Station of Quaternary Palaeontology and pollen atlases of Reille (1992) and Beug (2004). Pollen percentages were calculated based on the sum of trees/ shrubs (AP) and herbs (NAP), excluding aquatics and non-pollen palynomorphs. Local pollen assemblage zones (LPAZ) were defined by constrained incremental sum of squares cluster analysis (CONISS) with the software PAST (Hammer et al., 2001).

\section{Radiometric dating}

In order to establish a chronology for the composite profile, 28 samples of organic material (plant macrofossils, shells, bulk sediment) collected from the sediments as well as a recent algae (Table 1) were dated by accelerator mass spectrometry (AMS) ${ }^{14} \mathrm{C}$ dating at the Poznan Radiocarbon Laboratory. The resulting conventional radiocarbon ages were calibrated using OxCal 4.1 (Ramsey, 1995, 2001, 2009) with the IntCal09 calibration data set (Reimer et al., 2009). To further constrain the chronology, activity measurements for the short-lived radionuclides ${ }^{137} \mathrm{Cs}$ and ${ }^{241} \mathrm{Am}$ were carried out on dried and homogenized sediment samples, taken continuously at $0.5-\mathrm{cm}$-steps from the uppermost $10 \mathrm{~cm}$ of the sediment core. Measurements were conducted by gamma spectrometry using a high-efficiency, low-background well-type germanium detector (Canberra Industries GWC 2522-7500 SL) and processed with the software GENIE 2000 3.0. Counting statistics were better than $5 \%$ for ${ }^{137} \mathrm{Cs}(661 \mathrm{keV})$ and better than $20 \%$ for ${ }^{241} \mathrm{Am}(59.5 \mathrm{keV})$, except for samples with very low activities $\left(<0.002 \mathrm{~Bq} / \mathrm{g}{ }^{241} \mathrm{Am}\right)$. The measurement accuracy was validated using the standard reference materials IAEA-384 and 
Table I. AMS ${ }^{14} \mathrm{C}$ dates obtained from macrofossils and bulk sediment OM from composite profile SONK_II_DI/2. Conventional ${ }^{14} \mathrm{C}$ ages were calibrated using OxCal 4.I (Ramsey, I995, 200I, 2009) with the IntCal09 calibration data set (Reimer et al., 2009). Conventional ${ }^{14}$ C ages obtained from aquatic material and bulk sediment OM were corrected by - I50 years before calibration to consider the hardwater effect. Italicized samples were not considered for age modeling (for explanations see the results chapter).

\begin{tabular}{|c|c|c|c|c|c|}
\hline Sample/lab code & $\begin{array}{l}\text { Composite } \\
\text { depth }(\mathrm{cm})\end{array}$ & Dated material & $\begin{array}{l}\text { AMS }{ }^{14} \mathrm{C} \text { age } \\
(y r \text { BP } \pm \sigma)\end{array}$ & $\begin{array}{l}\text { Corr.AMS }{ }^{14} \mathrm{C} \text { age } \\
(\mathrm{yr} \mathrm{BP} \pm \sigma)\end{array}$ & 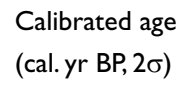 \\
\hline Poz-4759I & - & Recent Chara sp. & $155 \pm 30$ & - & $0-285$ \\
\hline Poz-53029 & 0.50 & Bulk sediment & $1070 \pm 30$ & $920 \pm 30$ & $765-923$ \\
\hline Poz-47326 & 11.00 & Shells ${ }^{\mathrm{a}}$ & $1310 \pm 25$ & $1160 \pm 25$ & $983-1172$ \\
\hline Poz-53030 & 11.00 & Bulk sediment & $1420 \pm 30$ & $1270 \pm 30$ & $1095-1286$ \\
\hline Poz-52033 & 20.50 & Shells ${ }^{\mathrm{a}}$ & $1400 \pm 30$ & $1250 \pm 30$ & $1081-1274$ \\
\hline Poz-5303I & 21.50 & Bulk sediment & $1400 \pm 30$ & $1250 \pm 30$ & $1081-1274$ \\
\hline Poz-44073 & 33.00 & Terrestrial plant remains ${ }^{b}$ & $1575 \pm 35$ & - & |389-1537 \\
\hline Poz-52038 & 33.00 & Bulk sediment & $1750 \pm 30$ & $1600 \pm 30$ & $1410-1546$ \\
\hline Poz-4398I & 39.00 & Shells $\mathrm{s}^{\mathrm{a}}$ & $1900 \pm 30$ & $1750 \pm 30$ & $|56|-\mid 734$ \\
\hline Poz-48591 & 41.50 & Terrestrial plant remains ${ }^{b}$ & $2120 \pm 35$ & $1970 \pm 35$ & $1830-1995$ \\
\hline Poz-52039 & 41.50 & Bulk sediment & $2030 \pm 35$ & $1880 \pm 35$ & $|72|-|89|$ \\
\hline Poz-48592 & 50.00 & Bulk sediment & $2430 \pm 30$ & $2280 \pm 30$ & $2159-2351$ \\
\hline Poz-47327 & 50.50 & Shells ${ }^{\mathrm{a}}$ & $2385 \pm 30$ & $2235 \pm 30$ & $2153-2338$ \\
\hline Poz-43983 & 63.50 & Shells ${ }^{a}$ & $2760 \pm 30$ & $2610 \pm 30$ & $27 \mid 5-2777$ \\
\hline Poz-47328 & 65.00 & Shells ${ }^{a}$ & $2815 \pm 35$ & $2665 \pm 35$ & $2744-2845$ \\
\hline Poz-48348 & 71.00 & Shells ${ }^{a}$ & $2995 \pm 30$ & $2845 \pm 30$ & $2870-3063$ \\
\hline Poz-52040 & 83.25 & Bulk sediment & $3305 \pm 35$ & $3155 \pm 35$ & $327 I-3450$ \\
\hline Poz-48593 & 98.50 & Bulk sediment & $3740 \pm 35$ & $3590 \pm 35$ & $3732-3985$ \\
\hline Poz-44074 & 121.00 & Terrestrial plant remains & $4200 \pm 35$ & - & $4620-4846$ \\
\hline Poz-52032 & 121.00 & Bulk sediment & $4465 \pm 35$ & $4315 \pm 35$ & $4835-4969$ \\
\hline Poz-47587 & 122.50 & Terrestrial plant remains ${ }^{b}$ & $4340 \pm 40$ & - & $4839-5036$ \\
\hline Poz-52034 & 122.50 & Bulk sediment & $4455 \pm 35$ & $4305 \pm 35$ & $4831-4965$ \\
\hline Poz-52035 & 122.50 & Terrestrial plant remains & $4320 \pm 35$ & - & $4836-4971$ \\
\hline Poz-48595 & 133.00 & Terrestrial plant remains & $4560 \pm 35$ & - & $5053-5439$ \\
\hline Poz-52036 & 138.00 & Bulk sediment & $4950 \pm 40$ & $4800 \pm 40$ & $5333-5607$ \\
\hline Poz-47588 & 139.50 & Terrestrial plant remains ${ }^{b}$ & $4700 \pm 40$ & - & $5320-5581$ \\
\hline Poz-48596 & $|4| .50$ & Terrestrial plant remains ${ }^{b}$ & $4960 \pm 40$ & - & $5600-5858$ \\
\hline Poz-48597 & 154.50 & Terrestrial plant remains & $5220 \pm 40$ & - & $5908-6176$ \\
\hline Poz-44072 & 154.50 & Terrestrial plant remains & $5580 \pm 35$ & - & $6297-6436$ \\
\hline
\end{tabular}

aPisidium nitidum.

bSample with small size (<I mg C).

IAEA-385, and a correction was applied for filling height (1.3$2.7 \mathrm{~cm})$ and sample weight $(0.8-2.0 \mathrm{~g})$.

\section{Results}

\section{Sediment core chronology}

Because of the limited number of terrestrial organic macros within the lake sediments, also several samples of aquatic material (shells, water plants, bulk sediment with unknown proportion of aquatic $\mathrm{OM})$ were selected for AMS ${ }^{14} \mathrm{C}$ dating. As such material is commonly regarded to give too old radiocarbon ages because of the incorporation of dissolved, ${ }^{14} \mathrm{C}$-depleted carbon, for example, from catchment rocks (Deevey et al., 1954; Olsson, 1986), a living deepwater algae (Poz-47591) from coring site D was dated to assess the recent hardwater effect and its possible impact on ${ }^{14} \mathrm{C}$ dates obtained from lacustrine materials. The obtained conventional radiocarbon age of $155 \pm 30{ }^{14} \mathrm{C} \mathrm{yr} \mathrm{BP}$ (Table 1) shows that the recent hardwater effect is rather small, but as this might have changed through time, several cross-datings on terrestrial and aquatic samples from the same stratigraphic level in the composite profile were carried out. As a result, conventional ages obtained from aquatic material are consistently only slightly older than those from terrestrial remains with partly overlapping $2 \sigma$ ranges after calibration, indicating a temporally relatively stable hardwater effect. Thus, a reservoir correction of -150 years, inferred from the age of the recent algae, was applied prior to calibration to all conventional ages derived from samples containing aquatic material (Table 1).

According to the presence of ${ }^{137} \mathrm{Cs}$ and ${ }^{241} \mathrm{Am}$ within the topmost sediments, which are exclusively of anthropogenic origin and occur in the environment only since the mid-20th century onset of atmospheric nuclear weapon testing, it is clear that the composite profile SONK_11_D1/2 is, in contrast to the sediment core investigated by Mathis et al. (2014), complete even for modern times. However, further pinning down the chronology using ${ }^{137} \mathrm{Cs}$ was impossible as the record revealed the constant occurrence of ${ }^{137} \mathrm{Cs}$ down to a sediment depth of $9 \mathrm{~cm}$ (Figure 4) without distinct peaks attributable to the maximum of thermonuclear weapon testing in 1963 or the Chernobyl reactor accident in 1986 (Appleby, 2001), likely owed to post-sedimentary diffusion of ${ }^{137} \mathrm{Cs}$ within the soft and water-saturated surface sediments (Davis et al., 1984; Klaminder et al., 2012). Instead, precise chronological information can be gained from ${ }^{241} \mathrm{Am}$, which is less mobile than ${ }^{137} \mathrm{Cs}$ and has a longer half life, making activity peaks easier detectable (Appleby et al., 1991). Accordingly, the strong ${ }^{241} \mathrm{Am}$ activity increase at $5.5 \mathrm{~cm}$ can be likely attributed to the onset of atmospheric nuclear weapon testing in 1950 at the former USSR test site Semipalatinsk, $\sim 1000 \mathrm{~km}$ north of Son Kol. Alternatively, it could represent the maximum in global atmospheric nuclear weapon testing in 1958-1962, but 


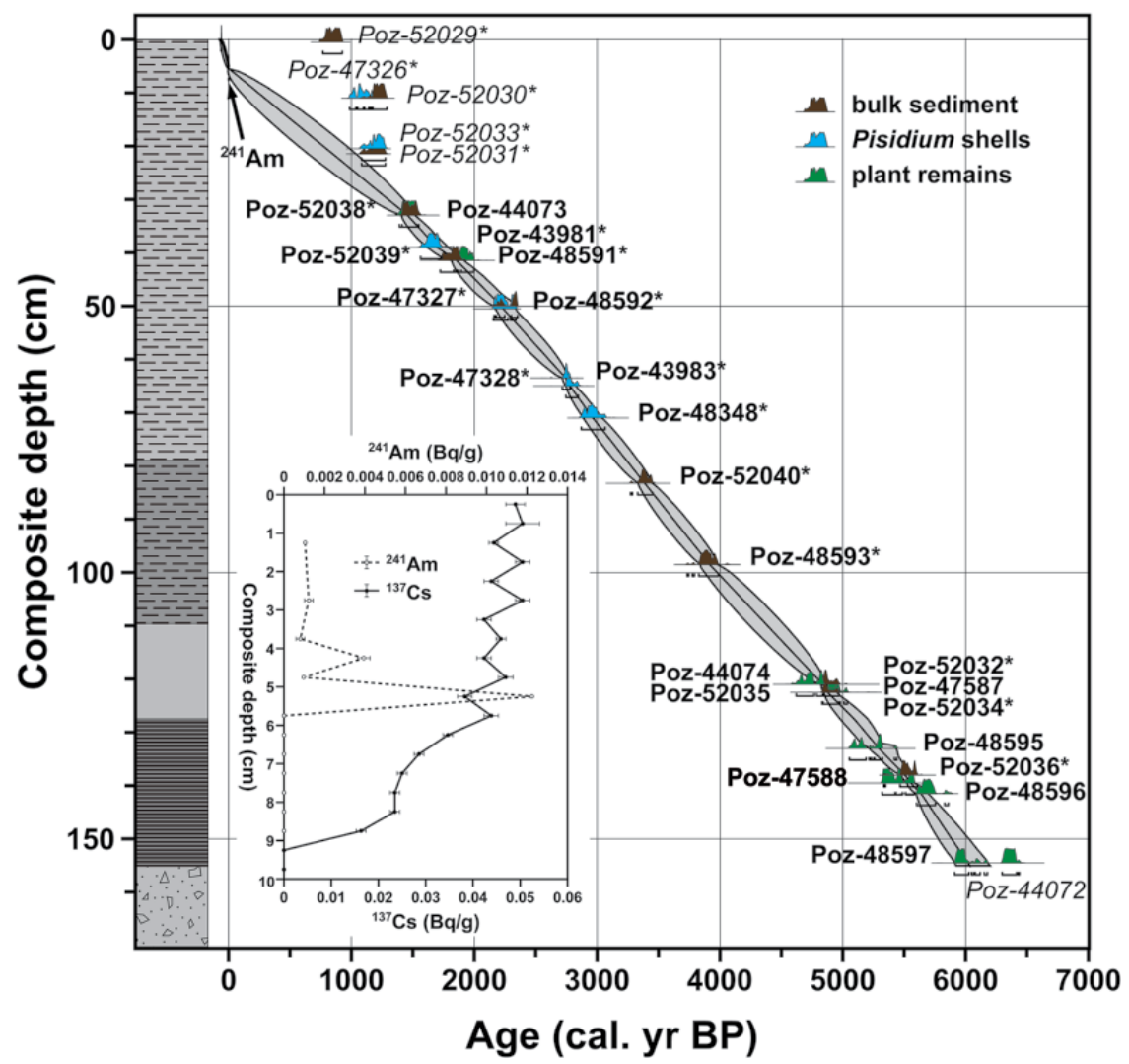

Figure 4. Age model of composite profile SONK_II_DI/2, derived from the $P$ Sequence depositional model (model parameter $k=2$ ) implemented in OxCal 4.I (Ramsey, I995, 200I, 2008). The solid line between individual radiocarbon dates represents the age model and the gray shading represents the $2 \sigma$ probability range. Individual AMS ${ }^{14} \mathrm{C}$ dates obtained from bulk sediment OM, Pisidium nitidum shells and terrestrial plant remains are displayed as calibrated $2 \sigma$ probability functions. Aquatic samples with asterisks were corrected for the hardwater effect prior to calibration and italicized samples were omitted from the age modeling procedure (for further details see the text). The inset shows results of ${ }^{137} \mathrm{Cs}$ and ${ }^{241} \mathrm{Am}$ activity measurements on the uppermost $10 \mathrm{~cm}$ of the composite profile.

such detailed age information cannot be reliably inferred from ${ }^{241} \mathrm{Am}$ because of the low sedimentation rate and comparatively large sampling interval $(0.5 \mathrm{~cm})$.

As the five radiocarbon ages obtained from the uppermost $c$. $20 \mathrm{~cm}$ of the composite profile (Poz-53029, Poz-47326, Poz53030, Poz-52033, and Poz-53031) contradict for inexplicable reasons the reliable results of ${ }^{241} \mathrm{Am}$ dating (e.g. the sediment surface dates to c. 750-900 cal. yr BP) and the inferred sedimentation rate development, they were rejected from age modeling. Also, one radiocarbon age from the base of the sediment sequence (Poz-44072) was rejected as it turned out to be $c .300$ years older than that of another sample (Poz-48597) from the same stratigraphic level, most likely owed to re-deposition of the dated material. In consequence, the age model for composite profile SONK_11_D1/2 (Figure 4) was finally established using the remaining 22 corrected conventional radiocarbon ages (Table 1) as well as the chronological fix points at $5.5 \mathrm{~cm}$ sediment depth (first occurrence of ${ }^{241} \mathrm{Am}$ : AD 1950) and at the sediment-water interface (date of the coring campaign: $\mathrm{AD}$ 2011) as input parameters for a $P_{-}$Sequence deposition model implemented in OxCal 4.1 (Ramsey, 2008). The high agreement index $\mathrm{A}_{\text {model }}$ of $94.2 \%$ proves the robustness of the chronology (Ramsey, 1995, 2001), which is furthermore independently constrained by pollen analyses, revealing the first appearance of (most likely long-distance-transported) Juglans pollen at $44.5 \mathrm{~cm}$ composite depth, i.e. at c. $2000 \mathrm{cal}$. yr $\mathrm{BP}$, which is in good agreement with the reported maximum age for the Kyrgyz walnut forests (Beer et al., 2008). According to the established age model, the geochemical/isotopic and biogeochemical data are multi-decadally resolved, while the resolution of the $\mu \mathrm{XRF}$ and pollen data is sub-annually and multi-centennially, respectively.

\section{Microfacies and geochemical/isotopic composition of the lake sediments}

The basal deposits (below $155.0 \mathrm{~cm}$ ) in composite profile SONK 11_D1/2 are older than c. 6000 cal. yr BP. They consist of light gray, clay-sized endogenic carbonate mud with abundant, mostly angular sand- to gravel-sized allochthonous minerogenic detritus (quartz, feldspars, carbonates, micas) randomly scattered within the carbonate matrix, but also contain allochthonous organics, ostracod valves, and lumps of reworked micritic lake marl. Because of the chaotic sediment microfacies, this unit is interpreted as a debris flow layer. Although it was impossible to penetrate this deposit, in situ lake sediments most likely occur below (Mathis et al., 2014). Above a sharp transition at the top of this deposit, the regular pelagic sediments of composite profile SONK $11 \mathrm{D} 1 / 2$ can be subdivided into four lithostratigraphical units (Figure $3 b$ ).

Unit I (155.0-127.5 cm/6000-5100 cal. yr BP) consists of irregularly laminated (sub-cm- to mm-scale) sediments with yellowish to light gray layers of micritic idiomorphic aragonite and calcite and brownish layers containing amorphous OM, algal material, ostracod valves, and diatom frustules. Minerogenic detritus (quartz, feldspars, micas) is abundant and randomly scattered within the sediments, reflected by strongly variable but generally high $\mathrm{Ti}$ and $\mathrm{K} \mu \mathrm{XRF}$ counts (Figure 5 ). $\mathrm{C} / \mathrm{N}$ ratios fluctuate between 8 and 10 and $\delta^{13} C_{\text {org }}$ ranges between $-19 \%$ and $-25 \%$, while $\delta^{15} \mathrm{~N}$ is fairly stable (3-5\%). Higher detrital contents at 


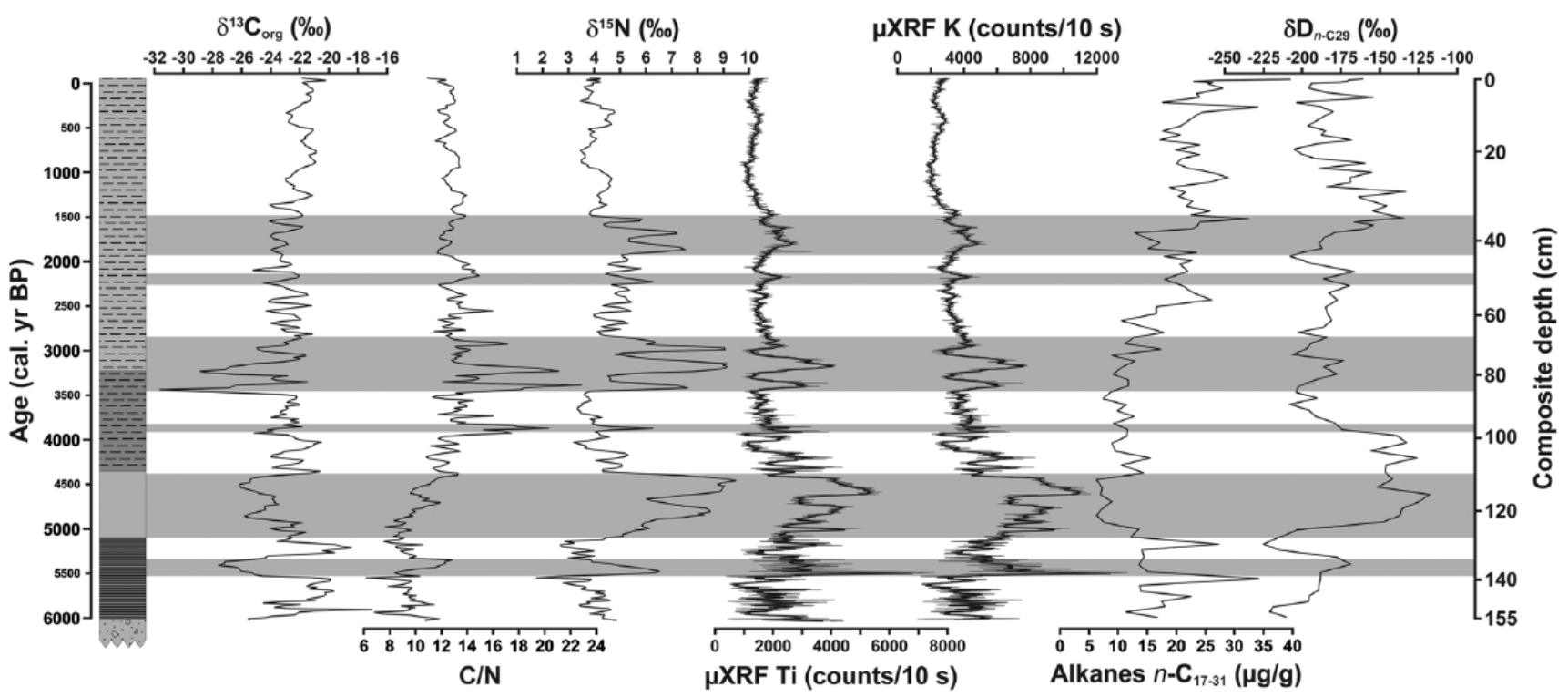

Figure 5. Results of stable isotope and (bio)geochemical $\left(\delta^{13} \mathrm{C}_{\text {org }}, \delta^{15} \mathrm{~N}, \mathrm{C} / \mathrm{N}, \mathrm{Ti}\right.$ and $\mathrm{K} \mu \mathrm{XRF}$ counts, total amount of $n$-alkanes $n-\mathrm{C}_{17-31}$, $\delta D_{n-C 29}$ analyses on the sediments of composite profile SONK_II_DI/2 from Son Kol.The black lines in the Ti and K $\mu$ XRF records represent 25-point running means. Gray bars highlight intervals of increased terrestrial input after enhanced spring snowmelt.

$5500-5300$ cal. yr BP are paralleled by more negative $\delta^{13} \mathrm{C}_{\text {org }}$ values (below $-27 \%$ ) and positive peaks in $\delta^{15} \mathrm{~N}(>6 \%$ ) and $\mathrm{C} / \mathrm{N}$ ratios (11-13).

Overlying unit II (127.5-109.5 cm/5100-4350 cal. yr BP) is characterized by homogenous, clay-sized light gray lake marl composed of endogenic calcite/aragonite with abundant ostracod valves but only very few amorphous OM and diatom frustules. The increased abundance of finely dispersed, siltsized $(\sim 50 \mu \mathrm{m})$ minerogenic detritus is reflected by strongly elevated Ti and $\mathrm{K} \mu \mathrm{XRF}$ counts (Figure 5 ). $\delta^{15} \mathrm{~N}$ values are the highest of the entire record, and two prominent peaks (up to ${ }_{8}-9 \%$ ) are paralleled by distinct negative $\delta^{13} \mathrm{C}_{\text {org }}$ spikes (below $-26 \%$ ). $\mathrm{C} / \mathrm{N}$ ratios gradually increase from 8 to 13 within this unit.

The sediment composition of unit III (109.5-79.0 $\mathrm{cm} / 4350-3250$ cal. yr BP) is almost similar to unit II, but ostracod valves are less abundant and the rather dark gray lake marl reveals a gradually upward-fading sub-cm-scale lightdark lamination, owed to fluctuations in $\mathrm{OM}$ and carbonate contents. Although the content of finely dispersed, silt-sized minerogenic detritus is generally rather low, two short-term increases, mirrored by slightly elevated $\mathrm{Ti}$ and $\mathrm{K} \mu \mathrm{XRF}$ counts, are observed at 3900-3850 and 3450-3300 cal. yr BP. $\mathrm{C} / \mathrm{N}$ ratios and $\delta^{15} \mathrm{~N}$ values are in general fairly stable, but also show prominent peaks (16-20 and 6-7\%, respectively) parallel to the increases in minerogenic detritus. $\delta^{13} \mathrm{C}_{\text {org }}$ is also rather stable, but shows distinct negative excursions (up to $-31 \%$ ) synchronous to the increases in the $\mathrm{C} / \mathrm{N}$ ratio, $\delta^{15} \mathrm{~N}$ values and detrital matter content.

The uppermost unit IV $(79.0-0.0 \mathrm{~cm} / 3250 \mathrm{cal}$. yr BP to present) consists of faintly $\mathrm{cm}$-scale layered yellowish gray lake marl (aragonite and calcite) with abundant amorphous OM and frequent Pisidium nitidum shells. The amount of silt-sized minerogenic detritus is generally reduced, except for increases at 3250-3050, 3000-2900, 2200-2150, and 1900-1500 cal. yr BP, reflected by elevated $\mathrm{Ti}$ and $\mathrm{K} \mu \mathrm{XRF}$ counts (Figure 5). Apart from two distinct peaks at 3250-3150 and 3000-2900 cal. yr BP, $\mathrm{C} / \mathrm{N}$ ratios are rather stable (11-15). $\delta^{13} \mathrm{C}_{\text {org }}$ fluctuates between $-21 \%$ and $-25 \%$, but shows negative spikes concomitant to the positive $\mathrm{C} / \mathrm{N}$ peaks and also at $2100 \mathrm{cal}$. yr BP. $\delta^{15} \mathrm{~N}$ also reveals distinct peaks $(>7 \%$ o) around 3250-3050, 3000-2850, 22502150, and 1900-1500 cal. yr BP.

\section{Geochemical/isotopic composition of the catchment samples}

Geochemical and isotopic compositions of modern OM samples from the lake and its catchment allow to characterize the predominant sources of lake sediment OM (Figure 6 and Supplementary Table S2, available online). Soils reveal a characteristic geochemical/isotopic signature, relatively close to that of the lake sediments. While soil $\delta^{15} \mathrm{~N}$ is slightly higher (between $5.8 \%$ and $12.3 \%$ ) than the average of the lake sediments, $\delta^{13} \mathrm{C}_{\text {org }}(-25.4$ to $-23.0 \%$ ) and $\mathrm{C} / \mathrm{N}$ ratios (9-14) plot in a similar range. In contrast, modern terrestrial plants show comparatively low $\delta^{15} \mathrm{~N}$ ( $-3.3 \%$ to $6.1 \%$ ) and $\delta^{13} \mathrm{C}_{\text {org }}$ values $(-21.7 \%$ to $-29.6 \%$ ), but clearly higher $\mathrm{C} / \mathrm{N}$ ratios (23-75). Animal dung is characterized by relatively narrow ranges of $\delta^{15} \mathrm{~N}(2.9-4.2 \%)$ and $\delta^{13} \mathrm{C}_{\text {org }}$ $\left(-27.5 \%\right.$ to $-27.9 \%$ ) as well as $\mathrm{C} / \mathrm{N}$ ratios $(25-28)$. $\delta^{15} \mathrm{~N}(3.2-$ $4.2 \%$ ) and $\delta^{13} \mathrm{C}_{\text {org }}$ values ( $-24.9 \%$ to $-28.7 \%$ ) of emerged aquatic macrophytes are on average fairly similar to those of the terrestrial vegetation, while $\mathrm{C} / \mathrm{N}$ ratios are distinctly lower (15$30)$. Submerged aquatic macrophytes and algae reveal $\delta^{15} \mathrm{~N}$ values of $-0.3 \%$ to $8.5 \%$ and relatively low $\mathrm{C} / \mathrm{N}$ ratios $(11-26)$. Overall, higher $\delta^{13} \mathrm{C}_{\text {org }}$ values ( $-10.0 \%$ to $-19.0 \%$ ) clearly separate them from other materials.

\section{Biogeochemistry of the lake sediments}

Sediments of the composite profile SONK_11_D1/2 contain $n$-alkanes of variable chain length $\left(n-\mathrm{C}_{15}\right.$ to $\left.n-\bar{C}_{33}\right)$ with a clearly bimodal distribution, maximizing at $n-\mathrm{C}_{29}(6.9 \pm 2.8 \mu \mathrm{g} / \mathrm{g})$ and $n-C_{31}(7.49 \pm 3 \mu \mathrm{g} / \mathrm{g})$. High fluctuations in the total amount of odd-numbered $n$-alkanes $n$ - $\mathrm{C}_{17-31}$ characterize lithostratigraphical unit I, while $\delta \mathrm{D}_{n-\mathrm{C} 29}$ is strongly depleted with minimum values of about $-225 \%$ (Figure 5). Within unit II, the total amount of $n$-alkanes $n-\mathrm{C}_{17-31}$ reaches a minimum after $4950 \mathrm{cal}$. yr BP and $\delta \mathrm{D}_{n-\mathrm{C} 29}$ shows a strong enrichment (more than $-150 \%$ ). Unit III is characterized by intermediate and relatively stable amounts of $n$-alkanes $n$ - $\mathrm{C}_{17-31} . \delta \mathrm{D}_{n \text {-C29 }}$ is still enriched until about $3900 \mathrm{cal}$. yr BP, but reveals clearly depleted values (around $-200 \%$ ) afterwards. Within unit IV, the total amount of $n$-alkanes $n$-C $\mathrm{C}_{17-31}$ shows an overall increasing trend with clear fluctuations. $\delta \mathrm{D}_{n-\mathrm{C} 29}$ reveals a slight increase towards the top of the record from the uppermost part of unit III, superimposed by a short-term enrichment at 1650-950 cal. yr BP. 

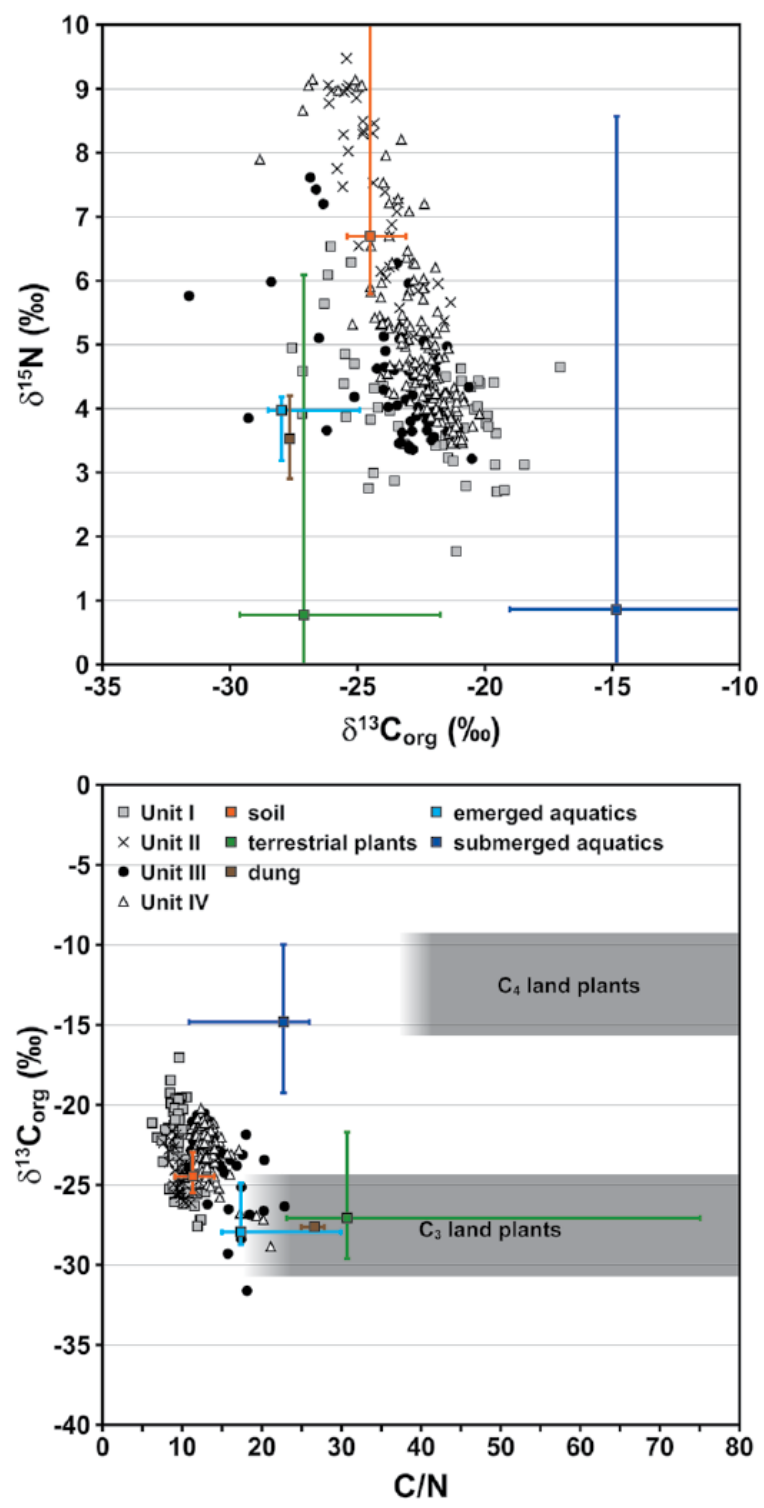

Figure 6. Geochemical and isotopic signatures $\left(\delta^{15} \mathrm{~N}\right.$ vs $\delta^{13} \mathrm{C}_{\text {org }}$ and $\delta^{13} \mathrm{C}_{\text {org }}$ vs $\mathrm{C} / \mathrm{N}$ ) of the Son Kol sediments compared with those of modern organic materials collected from the lake and its catchment. The latter are given as medians (squares) with total ranges (bars). Submerged aquatics include macrophytes and algae. For detailed values, see Supplementary Table S2 (available online).

\section{Pollen analyses}

The pollen record of composite profile SONK_11_D1/2 (Figure 7 ) is mainly dominated by steppe communities. Local sedge marshes and alpine meadows as well as the forest stands outside the valley are clearly underrepresented; arboreal pollen (mainly Picea, Juniperus, Betula), which most likely derives from longdistance eolian transport, is generally below 7\%. Throughout the record, pollen spectra show only small-scale changes, revealing a relatively stable ecosystem and timber line during the last 6000 years and confirming the vegetation development inferred for Son Kol by Mathis et al. (2014). The most notable feature of the record, separating LPAZ1 and LPAZ2, is the increase of Artemisia from about $40 \%$ to $60 \%$ at about $5000 \mathrm{cal}$. yr BP with a stable steppe community prevailing afterwards. Although the catchment is nowadays strongly influenced by livestock grazing and the presence of herding nomads in the Central Tian Shan is documented at least since the 1st millennium BC (Yablonsky, 1995), there is no indication for human impact throughout the pollen record.

\section{Discussion}

\section{Summer moisture conditions in Central Kyrgyzstan since the Mid-Holocene}

As recently shown, the $\delta \mathrm{D}$ of odd-numbered long-chain $n$-alkanes (e.g. $n-\mathrm{C}_{27}, n-\mathrm{C}_{29}$, and $n-\mathrm{C}_{31}$ ), which are major constituents of the epicuticular waxes of higher terrestrial plants (Eglinton and Hamilton, 1967; Maffei, 1996), reflects the $\delta \mathrm{D}$ composition of precipitation during the vegetation period at a respective site, modified by changes in evapotranspiration, relative humidity, and soil moisture (Sachse et al., 2004, 2006; Smith and Freeman, 2006). As high $\delta \mathrm{D}$ values are in this respect generally considered to reflect high leaf/soil evapotranspiration and thus low humidity, whereas low values correspond to relatively wet climate conditions (e.g. Liu and Huang, 2005), the $\delta \mathrm{D}_{n \text {-C29 }}$ record of the Son Kol sediments can be used to infer information about past summer moisture conditions.

In general, the $\delta \mathrm{D}_{n-\mathrm{C} 29}$ record confirms the previously proposed prevalence of humid conditions in mid-latitude arid Central Asia during the Mid-Holocene (at least between $c .6000$ and 5000 cal. yr BP) and the subsequent moderate drying trend until present times, which is thought to be caused by the gradual reduction of the intensity of the mid-latitude Westerlies and thus the amount of moisture provided during summer (Chen et al., 2008). However, as there were apparently significant differences in Holocene climate development between the western (e.g. Kyrgyzstan, Kazakhstan, Tajikistan, NW China) and eastern parts (e.g. Mongolia, NE China) of Central Asia (Kleinen et al., 2011; Rudaya et al., 2009), the Son Kol record is in the following mainly compared with other records from the same climatic domain.

Depleted $\delta \mathrm{D}_{n \text {-C29 }}$ values between 6000 and 4950 cal. yr BP (Figure 5) reflect an episode of predominantly humid summers at Son Kol. This coincides with indication for relatively wet climate conditions until about 5000 cal. yr BP in NW China (An et al., 2012; Li et al., 2011; Mischke and Wünnemann, 2006), Kazakhstan (Boomer et al., 2000), and Kyrgyzstan (Beer et al., 2007; Mathis et al., 2014). The humid Mid-Holocene at Son Kol was followed by a pronounced dry episode between 4950 and 3900 cal. yr BP (Figure 5). This observation is in line with dry phases documented in NW China (An et al., 2012; Li et al., 2011; Mischke and Wünnemann, 2006; Wünnemann et al., 2006) and a phase of lowered lake-levels in SE Kyrgyzstan at about the same time (Beer et al., 2007), together proving the regional significance of this dry episode. Interestingly, it is not reflected in the Son Kol pollen record (this study and Mathis et al., 2014), which could be explained by the relative stability and climatic insensitivity of the local montane steppe ecosystem, indicating that critical precipitation thresholds for significant vegetation changes might not have been crossed during this interval. This interpretation is confirmed by the missing indication for this dry episode in other regional records (e.g. Boomer et al., 2000; Ricketts et al., 2001), showing that site-specific hydrological conditions, internal thresholds of the respective ecosystems, the sensitivity of the investigated climate proxies, and the temporal resolution and dating accuracy of the individual records are of crucial importance for identifying such climate fluctuations. Subsequent to the pronounced dry interval, a return to again more humid summers is observed around 3900 cal. yr BP at Son Kol, followed by a gradual but moderate drying trend until present. This broadly coincides with similar observations in NW China (Mischke and Wünnemann, 2006; Wünnemann et al., 2006), Kazakhstan (Boomer et al., 2000), Tajikistan (Mischke et al., 2010), and Kyrgyzstan (Beer et al., 2007; Mathis et al., 2014; Ricketts et al., 2001), although the timing of the onset of the drying trend and its severity at the individual sites slightly differs, which might be owed to dating uncertainties and site characteristics. However, there is also local evidence for prevailing wet or rather fluctuating climate 


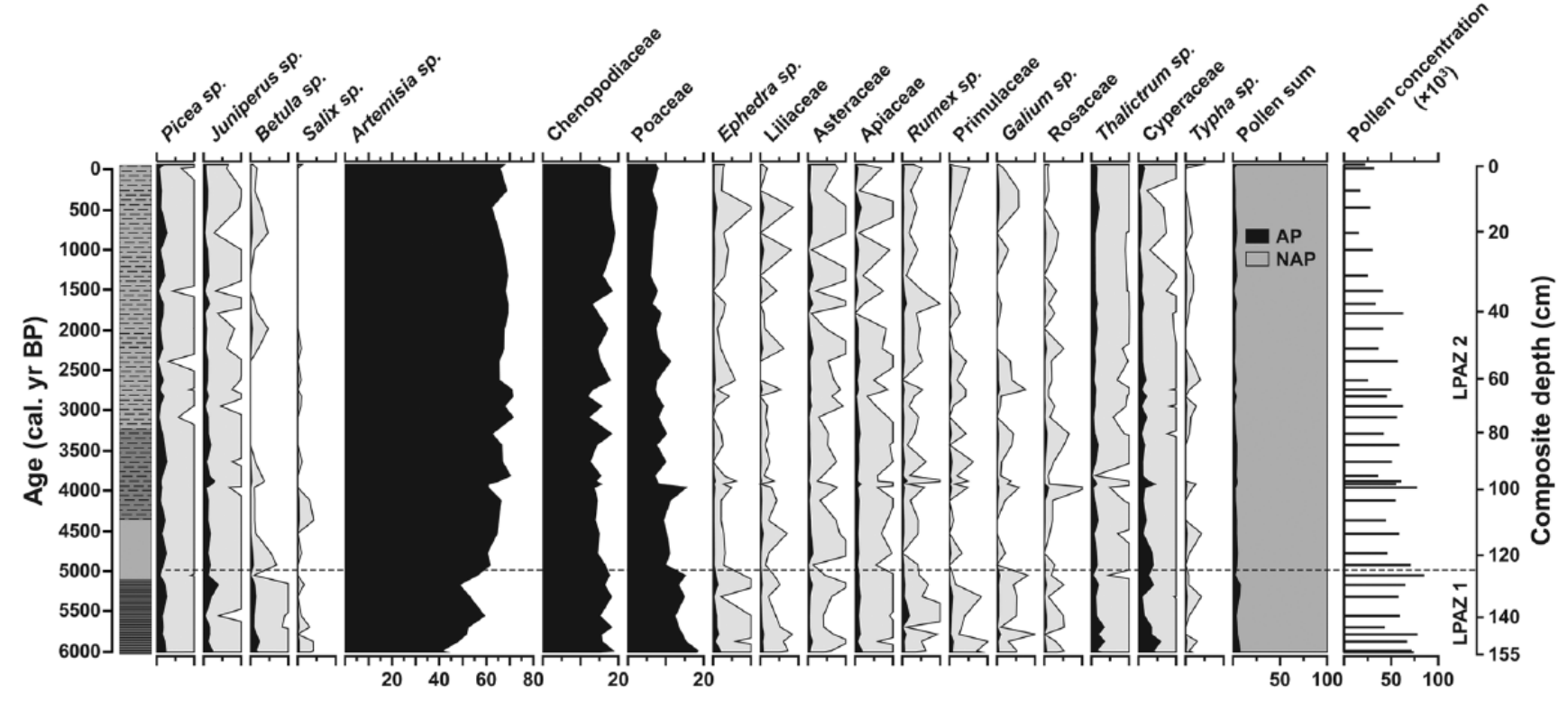

Figure 7. Pollen percentage/concentration diagram for selected taxa for composite profile SONK_II_DI/2 from Son Kol. Pollen abundances are presented as percentages of the total pollen sum (AP + NAP), excluding aquatics and non-pollen palynomorphs. Local pollen assemblage zones (LPAZ) were determined using CONISS. The outline curves represent a I0x exaggeration.

conditions during the Late Holocene in NW China (An et al., 2012; Liu et al., 2008; Rhodes et al., 1996), highlighting the spatial complexity of Late Holocene climate development in the region and the need for further investigations. Nevertheless, in summary, the overall evolution of summer moisture conditions during the last 6000 years at Son Kol with a rather wet Mid-Holocene and a subsequent moderate drying during the Late Holocene is in quite good agreement with results from other paleoclimate records in the western part of mid-latitude arid Central Asia.

\section{Phases of increased winter precipitation and hemispheric-scale climate teleconnections}

In addition to the biogeochemical data, information about past environmental and climatic changes at Son Kol can also be gained from the $\delta^{13} \mathrm{C}_{\text {org }}, \delta^{15} \mathrm{~N}$ and $\mathrm{C} / \mathrm{N}$ composition of lake sediment $\mathrm{OM}$. Facilitated by the characteristic geochemical/isotopic signatures of the different aquatic and terrestrial organic components involved in lake sediment formation, these parameters allow to track for instance changes in environmental conditions, productivity, nutrient availability, or the origin of OM (e.g. Hodell and Schelske, 1998; Hollander et al., 1992; Talbot, 2001; Talbot and Lærdal, 2000; Teranes and Bernasconi, 2000). While $\delta^{15} \mathrm{~N}$ is in this regard a partly ambiguous proxy because of the complexity of the nitrogen cycle and the various in-lake and catchment processes and nitrogen sources involved in lake sediment $\mathrm{OM}$ formation (Talbot, 2001), the $\delta^{13} \mathrm{C}_{\text {org }}$ and $\mathrm{C} / \mathrm{N}$ signatures of different organic materials are relatively well known. For example, freshwater phytoplankton is commonly characterized by low $\delta^{13} \mathrm{C}_{\text {org }}$ values ( -30 to $-20 \%$ ) and $\mathrm{C} / \mathrm{N}$ ratios $(<10)$, whereas $\mathrm{C}_{3}$ terrestrial plants and aquatic macrophytes reveal low $\delta^{13} \mathrm{C}_{\text {org }}$ values but high $\mathrm{C} / \mathrm{N}$ ratios $(>20)$, and $\mathrm{C}_{4}$ terrestrial plants are characterized by both high $\delta^{13} \mathrm{C}_{\text {org }}$ values (more than $-15 \%$ ) and $\mathrm{C} / \mathrm{N}$ ratios (e.g. Meyers and Teranes, 2001).

In general, these values are confirmed by the geochemical/isotopic signatures of modern OM samples from Son Kol and its catchment (Figure 6 and Supplementary Table S2, available online). Accordingly, Son Kol sediment OM represents a complex mixture of different sources with temporally variable contributions. However, soil and terrestrial plant OM (and partly also emerged aquatics) apparently prevail as their $\delta^{15} \mathrm{~N}, \delta^{13} \mathrm{C}_{\text {org }}$, and
$\mathrm{C} / \mathrm{N}$ signatures are most similar to those of the lake sediments (Figure 6). This is corroborated by the predominance of the longchain $n$-alkanes $n$ - $\mathrm{C}_{29}$ and $n-\mathrm{C}_{31}$ within the sediments, which derive from higher terrestrial plants (Eglinton and Hamilton, 1967; Maffei, 1996) and thus indicate a significant contribution of terrestrial material to sediment OM. Concerning the general geochemical/isotopic composition of the Son Kol sediments, the most striking feature are three distinct, multi-centennial phases of high $\delta^{15} \mathrm{~N}$ values at $5100-4350,3450-2850$, and $1900-1500$ cal. $\mathrm{yr} \mathrm{BP}$ as well as three short-term enrichments at 5500-5300, 3900-3850 and 2250-2200 cal. yr BP (Figure 5), which are paralleled by lowered $\delta^{13} \mathrm{C}_{\text {org }}$ values. High $\delta^{15} \mathrm{~N}$ values in the sediments could be attributed to (1) denitrification processes in an anoxic hypolimnion during periods of pronounced meromixis (Hodell and Schelske, 1998; Talbot and Lærdal, 2000), (2) increased aquatic productivity (Gu et al., 1996; Talbot and Lærdal, 2000; Teranes and Bernasconi, 2000), (3) evaporative loss of isotopically light ammonia during dry climate conditions (Talbot and Johannessen, 1992), or (4) increased input of terrestrial OM (Haberzettl et al., 2005; Mayr et al., 2009).

However, denitrification is unlikely to have caused elevated $\delta^{15} \mathrm{~N}$ values, as there is no sedimentological indication (e.g. varves and/or pyrite formation) for hypolimnetic anoxia within the respective intervals and sediment-dwelling ostracods (e.g. Limnocythere inopinata, Candona neglecta) and shells, which require well-oxygenized bottom waters, are also abundant. As evidence for a significantly deeper water body (e.g. abandoned shorelines) in the past is lacking, it is likely that the lake retained its present small depth-to-surface-area ratio at least since the MidHolocene and was, also in consequence of the large wind fetch, always well mixed as it is today, which is indicated by a high $\mathrm{O}_{2}$ saturation throughout the water column and almost no temperature stratification throughout the year (Figure $2 b$ and c). Furthermore, productivity changes can also be ruled out to have triggered high $\delta^{15} \mathrm{~N}$ values as $\delta^{15} \mathrm{~N}$ and $\delta^{13} \mathrm{C}_{\text {org }}$ are clearly anti-correlated throughout the sediment record (Figure 6), whereas the opposite is commonly regarded to reflect in-lake productivity changes (Finlay and Kendall, 2007; Hodell and Schelske, 1998; Talbot and Lærdal, 2000). Finally, also evaporative loss of isotopically light ammonia during dry climate conditions is unlikely to have caused increases in $\delta^{15} \mathrm{~N}$, as there is no clear correspondence between 
high- $\delta{ }^{15} \mathrm{~N}$-intervals and dry episodes reflected by the $\delta \mathrm{D}_{n-\mathrm{C} 29}$ record (Figure 5).

Hence, the only reasonable explanation for elevated $\delta^{15} \mathrm{~N}$ values in the lake sediments is input of terrestrial OM, particularly soil material. This is endorsed by the high similarity between the isotopic/geochemical signatures of the soils and lake sediment $\mathrm{OM}$ during high- $\delta^{15} \mathrm{~N}$-intervals and also the parallel increases of $\delta^{15} \mathrm{~N}$ and $\mathrm{Ti}$ and $\mathrm{K} \mu \mathrm{XRF}$ counts, the latter reflecting terrestrial minerogenic input (Figure 5). A similar correlation observed in lake sediments from Chile has recently also been interpreted in terms of increased soil input from the catchment (Haberzettl et al., 2005). The mechanism primarily responsible for high $\delta^{15} \mathrm{~N}$ values in soils is the enrichment of ${ }^{15} \mathrm{~N}$ during the mineralization/decomposition of terrestrial OM, which is influenced by several ecosystem variables, for example, climate, vegetation, soil composition, and depth as well as microbial processes (Amundson et al., 2003; Kendall, 1998). The ${ }^{15} \mathrm{~N}$-enriched soil OM is thereby mainly bound to minerogenic components (besides occurring as dissolved organic/inorganic nitrogen), which are easily transported to the lake basin by catchment erosion processes. In this context, it should be mentioned that $\mathrm{C} / \mathrm{N}$ ratios are in the case of Son Kol a rather ambiguous proxy for soil input. Although the catchment soils are characterized by elevated $\delta^{15} \mathrm{~N}$ values and relatively low $\mathrm{C} / \mathrm{N}$ ratios (Figure 6 and Supplementary Table S2, available online), lake sediment $\mathrm{C} / \mathrm{N}$ ratios reveal a strongly heterogeneous response during the individual intervals of increased soil input (Figure 5). This might be owed to variable contributions of plant $\mathrm{OM}$ with considerably higher $\mathrm{C} / \mathrm{N}$ ratios (Figure 6 and Supplementary Table S2, available online) during the individual intervals of increased allochthonous input.

Concerning the transport of soil material to the lake basin, eolian supply is rather unlikely as related deposits (loess) are generally restricted to lower altitudes, i.e. the piedmont regions of the Tian Shan (Machalett et al., 2006), and grain sizes of the detrital material within the high- $\delta^{15} \mathrm{~N}$-intervals are relatively large. Hence, soil input should be mainly related to fluvial transport processes, namely precipitation (reflecting wetter climate conditions in summer) or meltwater runoff (reflecting increased winter snowfall). As intervals of intensified terrestrial input do not explicitly correlate with phases of pronounced summer humidity but rather occur randomly during both dry and humid summer periods (indicated by high and low $\delta \mathrm{D}_{n-\mathrm{C} 29}$ values, respectively), they are consequently most likely not associated with summer precipitation but with increased winter snowfall and enhanced meltwater supply during subsequent spring thaw. This interpretation is corroborated by own field observations, revealing the perennial creeks around Son Kol almost completely desiccated during summer, although this is presently the season with the highest precipitation. Nevertheless, it should be mentioned that enhanced snowmelt and thus meltwater runoff might also be caused by increased temperatures, but since no explicitly temperature-related proxy data are available from the Son Kol sediments, this option remains speculative.

Considering also the basal debris flow in composite profile SONK_11_D1/2 as a meltwater-related deposit, distinct phases of enhanced winter precipitation in Central Kyrgyzstan occurred before c. 6000 and at 5100-4350, 3450-2850, and 1900-1500 cal. yr BP with an intriguing recurrence interval of $\sim 1500$ years. This closely matches a prominent low-frequency millennial-scale climate cyclicity of about 1500-1600 years observed in drift ice transport (Bond et al., 1997), ocean temperature conditions, and strength of the thermohaline circulation in the North Atlantic (Bianchi and McCave, 1999; Thornalley et al., 2009), but also in many other Northern Hemisphere paleoclimate records (Wanner et al., 2008). As recently shown, this cyclicity is not triggered by solar activity changes (Debret et al., 2007; Sorrel et al., 2012) but rather related to an ocean-internal variability of conveyor strength (Bianchi and McCave, 1999). As processes in the ocean are closely coupled to changes in atmospheric conditions in the North Atlantic realm, namely, the intensity of the mid-latitude westerly jet stream, similar periodicities are also apparent in wind strength in Iceland (Jackson et al., 2005) and storm activity in northern France (Sorrel et al., 2009), as well as in the amount of winter precipitation in southwestern Norway (Bjune et al., 2005) and the western Mediterranean (Fletcher et al., 2012). Since moisture supply to Central Kyrgyzstan is mainly controlled by the strength of the mid-latitude Westerlies (Aizen et al., 1997; Böhner, 2006), changes in their intensity observed in the North Atlantic realm should consequently also influence climate conditions at Son Kol. Indeed, snow-rich episodes in Central Kyrgyzstan reveal a close correspondence with millennial-scale increases in wind strength in Iceland (Jackson et al., 2005) and winter precipitation in southwestern Norway (Bjune et al., 2005), reflecting episodic intensifications of westerly atmospheric flow at high northern latitudes (Figure 8), as well as with the occurrence of drier winters and thus reduced westerly flow at lower latitudes, for example, in the western Mediterranean (Fletcher et al., 2012). This latitudinal pattern is characteristic for the present-day positive mode of the North Atlantic Oscillation (NAO; Hurrell, 1995), and it thus appears that enhanced winter precipitation in the Central Tian Shan is closely coupled to a strengthening of the Westerlies during positive NAO phases. In this context, the apparent discrepancy of weakened Westerlies in the western Mediterranean but enhanced westerly flow at about the same latitude in Central Asia might be explained by a longitudinally contrasting precipitation pattern: as indicated by data reanalysis and modeling studies, the southeastern Mediterranean (Black, 2012; Dünkeloh and Jacobeit, 2003) and western Central Asia (Syed et al., 2006, 2010) experience increased winter precipitation during positive NAO phases, while the western Mediterranean remains rather dry at these times (Fletcher et al., 2012). Hence, the $\sim 1500$-year cyclicity observed in snowfall intensity at Son Kol provides strong evidence for a significant impact of millennial-scale North Atlantic climate variability and particularly the NAO on winter precipitation conditions in Central Asia since the Mid-Holocene, a relation so far not shown for western Central Asia on longer timescales. However, as the relation between increased winter precipitation in the Tian Shan and NAO variability is still controversially debated (Aizen et al., 2001) and since also other remote influences on regional winter precipitation variability may exist (e.g. Syed et al., 2010), further studies are necessary to test the results from Son Kol and to fully understand the teleconnections exerting influence on winter precipitation variability in the western part of Central Asia.

\section{Conclusion}

Multi-proxy analyses of lake sediments from Son Kol (Central Kyrgyzstan) provide evidence for a predominant influence of the mid-latitude Westerlies on Holocene moisture evolution in this region. Following a wet Mid-Holocene and a pronounced dry phase between 4950 and 3900 cal. yr BP, a progressive but only moderate reduction of summer precipitation is observed during the Late Holocene, being in accordance with results from other regional paleoclimate records and mainly attributable to the gradually weakening influence of the Westerlies in mid-latitude arid Central Asia throughout the Holocene. However, changes in the intensity of the Westerlies, which are directly related to climate variability in the North Atlantic realm, apparently did not only influence summer precipitation patterns but also had a substantial impact on winter climate conditions in mid-latitude arid Central Asia. This is indicated by periods of enhanced detrital input through snowmelt, reflecting increased winter snowfall brought by the Westerlies, which occurred with a distinct periodicity of $\sim 1500$ 
(a)

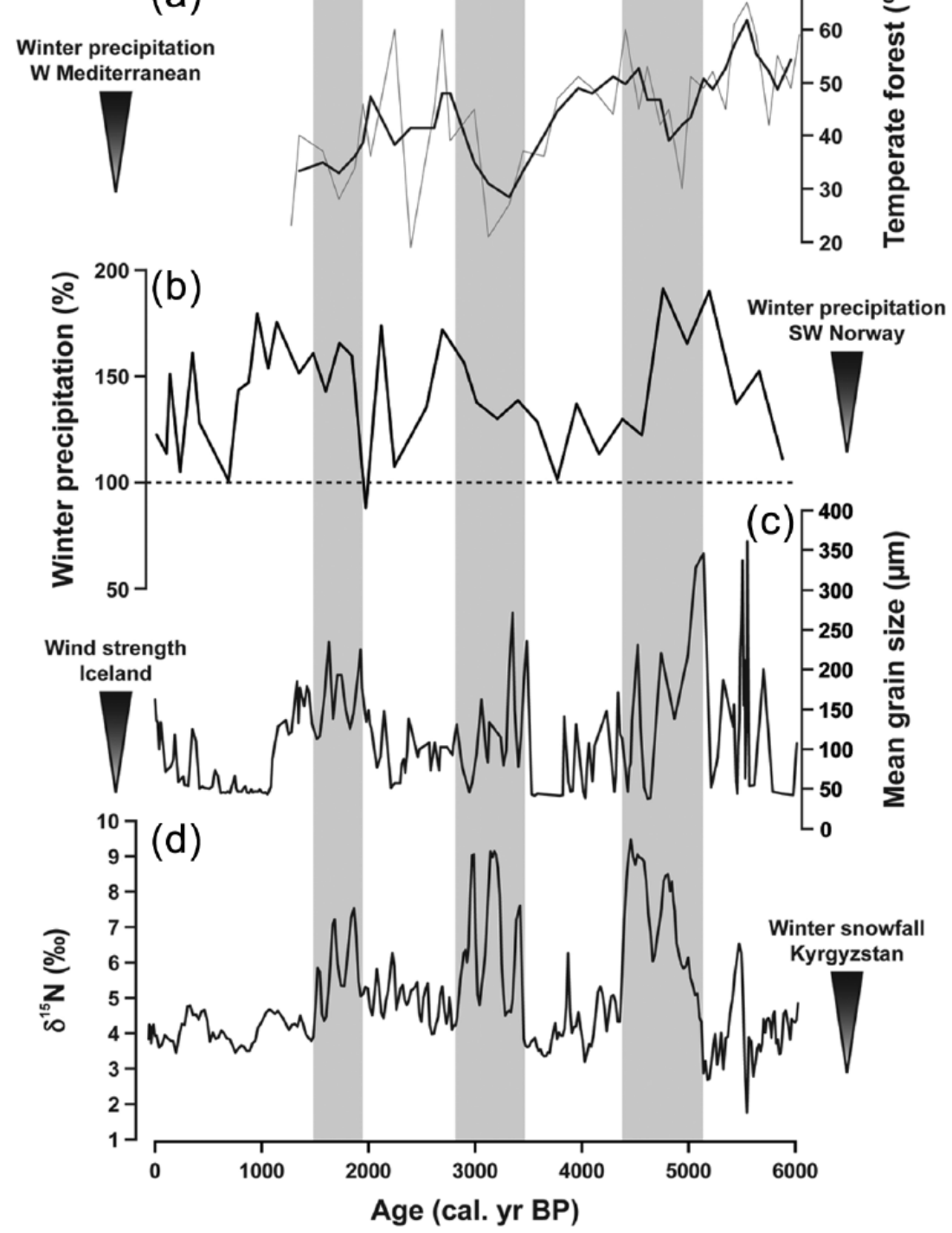

Figure 8. Hemispheric-scale comparison of climate records reflecting changes in the intensity of the wintertime Westerlies. (a) Changes in forest composition (percentage of temperate forest taxa) in the western Mediterranean as a proxy for winter precipitation (Fletcher et al., 2012). The gray line represents the original data, while the black line is a 3-point running mean. (b) Reconstructed amount of winter precipitation in southwestern Norway compared with the present-day level (100\%; Bjune et al., 2005). (c) Mean grain size of loess as a proxy for wind strength on Iceland (Jackson et al., 2005). (d) $\delta^{15} \mathrm{~N}$ of Son Kol sediments as a proxy for meltwater-derived input of soil material and thus snowfall intensity in Central Kyrgyzstan.

years. Synchronous low-frequency millennial-scale climate oscillations, attributed to changes in the strength and position of the westerly jet stream, have also been observed in several paleoclimate records in the North Atlantic realm, revealing a significant hemispheric-scale teleconnection between the North Atlantic and the Central Asian climate system and a possible impact of NAO variability on winter precipitation in the Central Tian Shan. However, understanding the underlying climatic mechanisms in full detail requires further investigations and more high-resolution paleoclimate records from the climatically sensitive region of midlatitude Central Asia.

\section{Acknowledgements}

We are indebted to the Central Asian Institute for Applied Geosciences (CAIAG) in Bishkek, particularly S Orunbaev, K Jusupova, and M Daiyrov, and the Karatal-Japyryk State Nature Reserve in Naryn for providing administrative, logistic, and field work support. We thank T Goslar (Poznań Radiocarbon Laboratory, Poznań) for AMS ${ }^{14} \mathrm{C}$ dating; S Pinkerneil, T Moldenhawer, and Y Beutlich (GFZ, Potsdam) for their help with the geochemical analyses; B Zimmermann and R Naumann (GFZ,
Potsdam) for XRD analyses; and G Arnold and D Berger (GFZ, Potsdam) for thin section preparation. V Otte (Senckenberg Museum of Natural History, Görlitz), D Lauterbach, and M Ristow (University of Potsdam, Potsdam) determined recent plant taxa, and U Bößneck (Justus Liebig University, Giessen) determined the bivalves. D Berger, R Schedel, D Henning (GFZ, Potsdam), and M Köhler (MKfactory, Potsdam) are acknowledged for their help during field work. The present manuscript greatly benefited from the constructive comments of three anonymous reviewers. All data from the Son Kol sediment presented in the figures are available via the PANGAEA network.

\section{Funding}

The CADY project as a part of the joint research program CAME (Central Asia and Tibet: Monsoon Dynamics and Geo-Ecosystems) has been funded by the German Federal Ministry of Education and Research (BMBF) through grant 03G0813.

\section{References}

Academy of Science of the Kyrgyz SSR (1987) Atlas of the Kyrgyz Soviet Socialistic Republic. Volume 1: Natural conditions 
and resources. Moscow: State Agency for Cartography and Geodesy, Central Directorate for Geodesy and Cartography, Council of Ministers of the USSR.

Aizen EM, Aizen VB, Melack JM et al. (2001) Precipitation and atmospheric circulation patterns at mid-latitudes of Asia. International Journal of Climatology 21: 535-556.

Aizen VB, Aizen EM, Melack JM et al. (1997) Climatic and hydrologic changes in the Tien Shan, Central Asia. Journal of Climate 10: 1393-1404.

Aizen VB, Aizen EM, Joswiak DR et al. (2006) Climatic and atmospheric circulation pattern variability from ice-core isotope/geochemistry records (Altai, Tien Shan and Tibet). Annals of Glaciology 43: 49-60.

Amundson R, Austin AT, Schuur EAG et al. (2003) Global patterns of the isotopic composition of soil and plant nitrogen. Global Biogeochemical Cycles 17: 1031.

An C-B, Lu Y, Zhao J et al. (2012) A high-resolution record of Holocene environmental and climatic changes from Lake Balikun (Xinjiang, China): Implications for Central Asia. The Holocene 22: 43-52.

Appleby PG (2001) Chronostratigraphic techniques in recent sediments. In: Last WM and Smol JP (eds) Tracking Environmental Change Using Lake Sediments. Volume I: Basin Analysis, Coring and Chronological Techniques. Dordrecht: Kluwer Academic Publishers, pp. 171-203.

Appleby PG, Richardson N and Nolan PJ (1991) ${ }^{241}$ Am dating of lake sediments. Hydrobiologia 214: 35-42.

Beer R, Heiri O and Tinner W (2007) Vegetation history, fire history and lake development recorded for 6300 years by pollen, charcoal, loss on ignition and chironomids at a small lake in southern Kyrgyzstan (Alay Range, Central Asia). The Holocene 17: 977-985.

Beer R, Kaiser F, Schmidt K et al. (2008) Vegetation history of the walnut forests in Kyrgyzstan (Central Asia): Natural or anthropogenic origin? Quaternary Science Reviews 27: 621632.

Berglund BE and Ralska-Jasiewiczowa M (1986) Pollen analysis. In: Berglund BE (ed.) Handbook of Holocene Palaeoecology and Palaeohydrology. Berglund: John Wiley \& Sons, pp. 455-484.

Bergmann J, Friedel P and Kleeberg R (1998) BGMN - A new fundamental parameters based Rietveld program for laboratory X-ray sources, it's use in quantitative analysis and structure investigations. CPD Newsletter, No. 20, 5-8.

Beug H-J (2004) Leitfaden der Pollenbestimmung für Mitteleuropa und angrenzende Gebiete. München: Verlag Dr. Friedrich Pfeil.

Bianchi GG and McCave IN (1999) Holocene periodicity in North Atlantic climate and deep-ocean flow south of Iceland. Nature 397: 515-517.

Bjune AE, Bakke J, Nesje A et al. (2005) Holocene mean July temperature and winter precipitation in western Norvay inferred from palynological and glaciological lake-sediment proxies. The Holocene 15: 177-189.

Black E (2012) The influence of the North Atlantic Oscillation and European circulation regimes on the daily to interannual variability of winter precipitation in Israel. International Journal of Climatology 32: 1654-1664.

Böhner J (2006) General climatic controls and topoclimatic variations in Central and High Asia. Boreas 35: 279-295.

Bond G, Showers WJ, Cheseby M et al. (1997) A pervasive millennial-scale cycle in North Atlantic Holocene and glacial climates. Science 278: 1257-1266.

Boomer I, Aladin N, Plotnikov I et al. (2000) The palaeolimnology of the Aral Sea: A review. Quaternary Science Reviews 19: $1259-1278$.
Brauer A, Endres C and Negendank JFW (1999) Lateglacial calendar year chronology based on annually laminated sediments from Lake Meerfelder Maar, Germany. Quaternary International 61: 17-25.

Chen F, Yu Z, Yang M et al. (2008) Holocene moisture evolution in arid central Asia and its out-of-phase relationship with Asian monsoon history. Quaternary Science Reviews 27: 351-364.

Cheng H, Zhang PZ, Spötl C et al. (2012) The climatic cyclicity in semiarid-arid central Asia over the past 500,000 years. Geophysical Research Letters 39: L01705.

Croudace IW, Rindby A and Rothwell RG (2006) ITRAX: Description and evaluation of a new multi-function X-ray core scanner. In: Rothwell RG (ed.) New Techniques in Sediment Core Analysis. Bath: Geological Society (Special Publications 267), pp. 51-63.

Davis RB, Hess CT, Norton SA et al. (1984) ${ }^{137} \mathrm{Cs}$ and ${ }^{210} \mathrm{~Pb}$ dating of sediments from soft-water lakes in New England (U.S.A.) and Scandinavia, a failure of ${ }^{137} \mathrm{Cs}$ dating. Chemical Geology 44: 151-185.

Debret M, Bout-Roumazeilles V, Grousset F et al. (2007) The origin of the 1500-year climate cycles in Holocene NorthAtlantic records. Climate of the Past 3: 569-575.

Deevey ES, Gross MS, Hutchinson GE et al. (1954) The natural $\mathrm{C}^{14}$ contents of materials from hard-water lakes. Proceedings of the National Academy of Sciences of the United States of America 40: 285-288.

De Grave J, Glorie S, Buslov MM et al. (2011) The thermotectonic history of the Song-Kul plateau, Kyrgyz Tien Shan: Constraints by apatite and titanite thermochronometry and zircon U/Pb dating. Gondwana Research 20: 745-763.

Dünkeloh A and Jacobeit J (2003) Circulation dynamics of Mediterranean precipitation variability 1948-98. International Journal of Climatology 23: 1843-1866.

Eglinton G and Hamilton RJ (1967) Leaf epicuticular waxes. Science 156: 1322-1335.

Esper J, Shiyatov SG, Mazepa VS et al. (2003) Temperaturesensitive Tien Shan tree ring chronologies show multi-centennial growth trends. Climate Dynamics 21: 699-706.

Finlay JC and Kendall C (2007) Stable isotope tracing of temporal and spatial variability in organic matter sources to freshwater ecosystems. In: Michener R and Lajtha K (eds) Stable Isotopes in Ecology and Environmental Science. Oxford: Blackwell Publishing, pp. 283-333.

Fletcher WJ, Debret M and Sanchez-Goñi MF (2012) MidHolocene emergence of a low-frequency millennial oscillation in western Mediterranean climate: Implications for past dynamics of the North Atlantic atmospheric Westerlies. The Holocene 23: 153-166.

Gu B, Schelske CL and Brenner M (1996) Relationship between sediment and plankton isotope ratios $\left(\delta^{13} \mathrm{C}\right.$ and $\left.\delta^{15} \mathrm{~N}\right)$ and primary productivity in Florida lakes. Canadian Journal of Fisheries and Aquatic Sciences 53: 875-883.

Haberzettl T, Fey M, Lücke A et al. (2005) Climatically induced lake level changes during the last two millennia as reflected in sediments of Laguna Potrok Aike, Southern Patagonia (Santa Cruz, Argentina). Journal of Paleolimnology 33: 283-302.

Hammer Ø, Harper DAT and Ryan PD (2001) PAST: Paleontological statistics software package for education and data analysis. Palaeontologia Electronica 4: 1-9.

Hodell DA and Schelske CL (1998) Production, sedimentation, and isotopic composition of organic matter in Lake Ontario. Limnology and Oceanography 43: 200-214.

Hollander DJ, McKenzie JA and ten Haven HL (1992) A 200 year sedimentary record of progressive eutrophication in Lake 
Greifen (Switzerland): Implications for the origin of organiccarbon-rich sediments. Geology 20: 825-828.

Huang X, Oberhänsli H, Mathis M et al. (2012) A Holocene lacustrine record of Lake Sonkul: Hydro-climatic changes in central Asia and possible interactions between Westerlies and Asian monsoon. In: EGU General Assembly 2012 (Geophysical Research Abstracts, vol. 14, EGU2012-6660), 23-27 April, Vienna.

Huang X, Oberhänsli H, von Suchodoletz H et al. (2011) Dust deposition in the Aral Sea: Implications for changes in atmospheric circulation in central Asia during the past 2000 years. Quaternary Science Reviews 30: 3661-3674.

Hurrell JW (1995) Decadal trends in the North Atlantic Oscillation: Regional temperatures and precipitation. Science 269: 676-679.

Jackson MG, Oskarsson N, Trønnes RG et al. (2005) Holocene loess deposition in Iceland: Evidence for millennial-scale atmosphere-ocean coupling in the North Atlantic. Geology 33: 509-512.

Jarvis A, Reuter HI, Nelson A et al. (2008) Hole-filled seamless SRTM data V4. International Centre for Tropical Agriculture (CIAT). Available at: http://srtm.csi.cgiar.org.

Kendall C (1998) Tracing nitrogen sources and cycling in catchments. In: Kendall C and McDonnell JJ (eds) Isotope Tracers in Catchment Hydrology. Amsterdam: Elsevier, pp. 519-576.

Klaminder J, Appleby PG, Crook P et al. (2012) Post-deposition diffusion of ${ }^{137} \mathrm{Cs}$ in lake sediment: Implications for radiocaesium dating. Sedimentology 59: 2259-2267.

Kleinen T, Tarasov P, Brovkin V et al. (2011) Comparison of modeled and reconstructed changes in forest cover through the past 8000 years: Eurasian perspective. The Holocene 21: 723-734.

Liu W and Huang Y (2005) Compound specific D/H ratios and molecular distributions of higher plant leaf waxes as novel paleoenvironmental indicators in the Chinese Loess Plateau. Organic Geochemistry 36: 851-860.

Liu X, Herzschuh U, Shen J et al. (2008) Holocene environmental and climatic changes inferred from Wulungu Lake in northern Xinjiang, China. Quaternary Research 70: 412-425.

Li X, Zhao K, Dodson J et al. (2011) Moisture dynamics in central Asia for the last $15 \mathrm{kyr}$ : New evidence from Yili Valley, Xinjiang, NW China. Quaternary Science Reviews 30: 3457-3466.

Machalett B, Frechen M, Hambach U et al. (2006) The loess sequence from Remisowka (northern boundary of the Tien Shan Mountains, Kazakhstan) - Part I: Luminescence dating. Quaternary International 152-153: 192-201.

Machalett B, Oches EA, Frechen M et al. (2008) Aeolian dust dynamics in central Asia during the Pleistocene: Driven by the long-term migration, seasonality, and permanency of the Asiatic polar front. Geochemistry Geophysics Geosystems 9: Q08Q09.

Maffei M (1996) Chemotaxonomic significance of leaf wax alkanes in the gramineae. Biochemical Systematics and Ecology 24: 53-64.

Mathis M, Sorrel P, Klotz S et al. (2014) Regional vegetation patterns at lake Son Kul reveal Holocene climatic variability in central Tien Shan (Kyrgyzstan, Central Asia). Quaternary Science Reviews 89: 169-185.

Mayr C, Lücke A, Maidana N et al. (2009) Isotopic fingerprints on lacustrine organic matter from Laguna Potrok Aike (southern Patagonia, Argentina) reflect environmental changes during the last 16,000 years. Journal of Paleolimnology 42: 81-102.

Meyers PA and Teranes JL (2001) Sediment organic matter. In: Last WM and Smol JP (eds) Tracking Environmental Change Using Lake Sediments. Volume 2: Physical and Geochemical Methods. Dordrecht: Kluwer Academic Publishers, pp. 239-269.
Mischke S and Wünnemann B (2006) The Holocene salinity history of Bosten Lake (Xinjiang, China) inferred from ostracod species assemblages and shell chemistry: Possible palaeoclimatic implications. Quaternary International 154-155: $100-112$.

Mischke S, Rajabov I, Mustaeva N et al. (2010) Modern hydrology and late Holocene history of Lake Karakul, eastern Pamirs (Tajikistan): A reconnaissance study. Palaeogeography Palaeoclimatology Palaeoecology 289: 10-24.

Olsson IU (1986) Radiometric dating. In: Berglund BE (ed.) Handbook of Holocene Palaeoecology and Palaeohydrology. Chichester: John Wiley \& Sons, pp. 273-312.

Ramsey CB (1995) Radiocarbon calibration and analysis of stratigraphy: The OxCal program. Radiocarbon 37: 425-430.

Ramsey CB (2001) Development of the radiocarbon calibration program. Radiocarbon 43: 355-363.

Ramsey CB (2008) Deposition models for chronological records. Quaternary Science Reviews 27: 42-60.

Ramsey CB (2009) Bayesian analysis of radiocarbon dates. Radiocarbon 51: 337-360.

Reille M (1992) Pollen et Spores d'Europe et d'Afrique du Nord. Marseille: Laboratoire de Botanique Historique et Palynologie, CNRS.

Reimer PJ, Baillie MGL, Bard E et al. (2009) IntCal09 and Marine09 radiocarbon age calibration curves, $0-50,000$ years cal BP. Radiocarbon 51: 1111-1150.

Rhodes TE, Gasse F, Lin R et al. (1996) A Late Pleistocene-Holocene lacustrine record from Lake Manas, Zunggar (northern Xinjiang, western China). Palaeogeography Palaeoclimatology Palaeoecology 120: 105-121.

Ricketts RD, Johnson TC, Brown ET et al. (2001) The Holocene paleolimnology of Lake Issyk-Kul, Kyrgyzstan: Trace element and stable isotope composition of ostracodes. Palaeogeography Palaeoclimatology Palaeoecology 176: 207-227.

Rudaya N, Tarasov P, Dorofeyuk N et al. (2009) Holocene environments and climate in the Mongolian Altai reconstructed from the Hoton-Nur pollen and diatom records: A step towards better understanding climate dynamics in Central Asia. Quaternary Science Reviews 28: 540-554.

Sachse D, Radke J and Gleixner G (2004) Hydrogen isotope ratios of recent lacustrine sedimentary n-alkanes record modern climate variability. Geochimica et Cosmochimica Acta 68: 4877-4889.

Sachse D, Radke J and Gleixner G (2006) $\delta$ D values of individual $n$-alkanes from terrestrial plants along a climatic gradient Implications for the sedimentary biomarker record. Organic Geochemistry 37: 469-483.

Shnitnikov AV (1980) Ozera Tian-Shanya i ikh istoriya [Lakes of the Tian Shan and Their History]. Leningrad: Nauka.

Smith FA and Freeman KH (2006) Influence of physiology and climate on $\delta \mathrm{D}$ of leaf wax n-alkanes from $\mathrm{C}_{3}$ and $\mathrm{C}_{4}$ grasses. Geochimica et Cosmochimica Acta 70: 1172-1187.

Solomon S, Qin D, Manning M et al. (eds) (2007) Climate Change 2007: The Physical Science Basis (Contribution of Working Group I to the Fourth Assessment Report of the Intergovernmental Panel on Climate Change). Cambridge: Cambridge University Press.

Sorrel P, Debret M, Billeaud I et al. (2012) Persistent non-solar forcing of Holocene storm dynamics in coastal sedimentary archives. Nature Geoscience 5: 892-896.

Sorrel P, Popescu SM, Head MJ et al. (2006) Hydrographic development of the Aral Sea during the last 2000 years based on a quantitative analysis of dinoflagellate cysts. Palaeogeography Palaeoclimatology Palaeoecology 234: 304-327.

Sorrel P, Tessier B, Demory F et al. (2009) Evidence for millennial-scale climatic events in the sedimentary infilling of a 
macrotidal estuarine system, the Seine estuary (NW France). Quaternary Science Reviews 28: 499-516.

Stockmarr J (1971) Tablets with spores used in absolute pollen analysis. Pollen et Spores 13: 615-621.

Syed FS, Giorgi F, Pal JS et al. (2006) Effect of remote forcings on the winter precipitation of central southwest Asia part 1: Observations. Theoretical and Applied Climatology 86: 147-160.

Syed FS, Giorgi F, Pal JS et al. (2010) Regional climate model simulation of winter climate over Central-Southwest Asia, with emphasis on NAO and ENSO effects. International Journal of Climatology 30: 220-235.

Talbot MR (2001) Nitrogen isotopes in palaeolimnology. In: Last WM and Smol JP (eds) Tracking Environmental Change Using Lake Sediments. Volume 2: Physical and Geochemical Methods. Dordrecht: Kluwer Academic Publishers, pp. 401-439.

Talbot MR and Johannessen T (1992) A high resolution palaeoclimatic record for the last 27,500 years in tropical West Africa from the carbon and nitrogen isotopic composition of lacustrine organic matter. Earth and Planetary Science Letters 110: 23-37.

Talbot MR and Lærdal T (2000) The Late Pleistocene - Holocene palaeolimnology of Lake Victoria, East Africa, based upon elemental and isotopic analyses of sedimentary organic matter. Journal of Paleolimnology 23: 141-164.
Teranes JL and Bernasconi SM (2000) The record of nitrate utilization and productivity limitation provided by $\delta^{15} \mathrm{~N}$ values in lake organic matter - A study of sediment trap and core sediments from Baldeggersee, Switzerland. Limnology and Oceanography 45: 801-813.

Thornalley DJR, H Elderfield and McCave IN (2009) Holocene oscillations in temperature and salinity of the surface subpolar North Atlantic. Nature 457: 711-714.

Wanner H, Beer J, Bütikofer J et al. (2008) Mid- to Late Holocene climate change: An overview. Quaternary Science Reviews 27: 1791-1828.

Werner RA and Brand WA (2001) Referencing strategies and techniques in stable isotope ratio analysis. Rapid Communications in Mass Spectrometry 15: 501-519.

Williams MW and Konovalov VG (2008) Central Asia Temperature and Precipitation Data, 1879-2003. Boulder, CO: National Snow and Ice Data Center. Available at: http:// dx.doi.org/10.7265/N5NK3BZ8.

Wünnemann B, Mischke S and Chen F (2006) A Holocene sedimentary record from Bosten Lake, China. Palaeogeography Palaeoclimatology Palaeoecology 234: 223-238.

Yablonsky LT (1995) The material culture of the Saka and historical reconstruction. In: Davis-Kimball J, Bashilov VA and Yablonsky LT (eds) Nomads of the Eurasian Steppes in the Early Iron Age. Berkeley, CA: Zinat Press, pp. 201-239. 